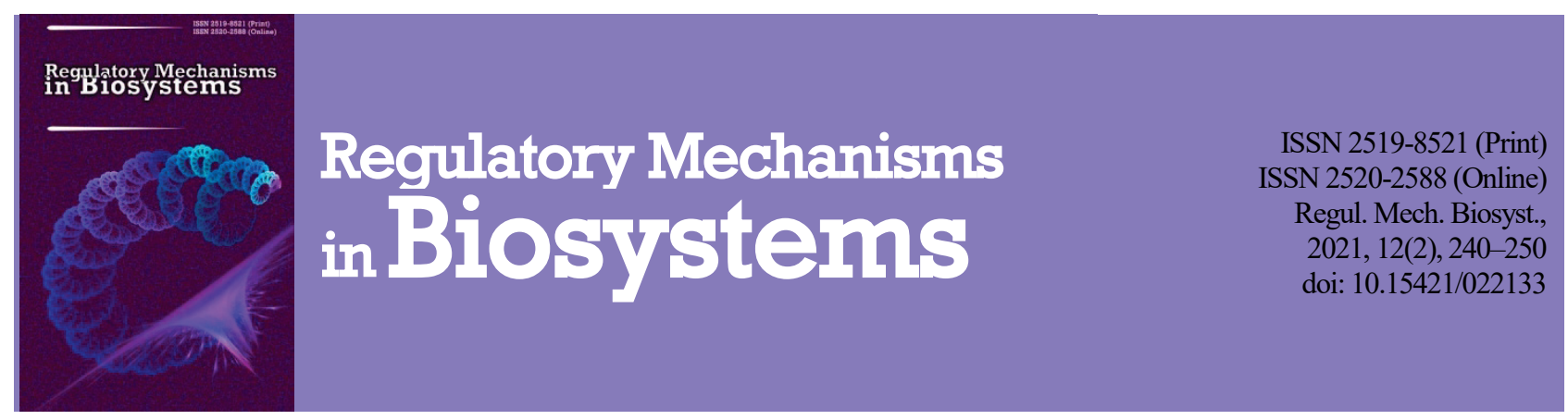

\title{
Impact of habitation conditions on metabolism in the muscles, liver, and gonads of different sex and age groups of bream
}

\author{
A. A. Payuta*, E. A. Flerova** \\ P. G. Demidov Yaroslavl State University, Yaroslavl, Russia
}

Article info

Received 29.03.2021

Received in revised form 23.04.2021

Accepted 25.04.2021

\begin{abstract}
Payuta, A. A., \& Flerova, E. A. (2021). Impact of habitation conditions on metabolism in the muscles, liver, and gonads of different sex and age groups of bream. Regulatory Mechanisms in Biosystems, 12(2), 240-250. doi:10.15421/022133
\end{abstract}

P. G. Demidov Yaroslavl State University

Sovetskaya st., 14 ,

Yaroslavl, 150003, Russia.

Tel.: 48-52-797-702.

E-mail:a.payuta@mail.ru

Impact of the factors of the aquatic environment is an inevitable aspect of the life of fish as poikilothermic animals and provokes responses in their organisms. The study focused on determining peculiarities in the composition of the metabolic products in the tissues of different age and sex groups of common bream Abramis brama (L.) depending on the living conditions in the water reservoirs of the Upper Volga. The fish were captured in the fattening period in summer and autumn, measured, weighed, identifying sex, maturity stage of the gonads and age. In the muscles, liver and gonads of bream, we analyzed the contents of water, dry matter, lipids, protein, ash and carbohydrates using the standard techniques. The contents of biochemical components in the organism of bream were to a higher degree determined by the peculiarities of the living conditions rather than sex and age of the individuals. In the muscles and liver of bream living in the conditions of increased water temperature and low concentration of oxygen, the concentrations of protein and ash were lower. In the same tissues of bream from the water bodies with high concentrations of pollutants in the water and benthic deposits, we found increased fat content. The muscles of male bream contained less protein and more carbohydrates than females and juvenile individuals, and the muscles of juveniles had less fat. The environmental factors had greater influence on the content of the metabolic products in the liver of bream than sex, and only females had higher ash content than males. The testes had more fat and less protein than the ovaries. During the transition of the gonads from maturity stage II to III, the contents of dry matter and lipids in them decreased. We determined that the environmental factors have stronger impact on biochemical parameters in the tissues of bream than age, because we found no general age patterns in the dynamics of biochemical components, except the liver, in which the highest content of organic compounds was found in individuals aged 6 to 10 years. Water heated by the Hydro Power Plant positively influenced the young bream, as indicated by higher content of metabolic products in individuals aged 5+ than older groups and bream from the surveyed water bodies. Monitoring of the physiological condition of bream focusing on the contents of metabolic products in the tissues may provide necessary data for successful regulation of bream populations in the water reservoirs of the Upper Volga.

Keywords: Abramis brama; protein; fat; proximate composition; water temperature; pollution of bed deposits.

\section{Introduction}

The patterns of the relationships between fish and abiotic and anthropogenic factors are among the problems studied within the scope of hydrobiology, because the effects of the environment such as fluctuation of water temperature, $\mathrm{pH}$, oxygen, hydraulic regimes, pollutants and other are an inevitable aspect of life of fish as poikotherm animals (Shuter et al., 1989; Ali et al., 2005; Fang et al., 2010; Guiet et al., 2016; Santos et al., 2020). In order to analyze the responses of the organism to the environmental factors, biomarkers are used, the most successful being considered histological, biochemical and physiological parameters. Indicators of metabolism attract great scientific interest, for their content may change due to the effects of various factors of the aquatic environment (Larsson et al., 1984; Lund et al., 2011; Collier et al., 2013; Filippov et al., 2017). This specificity of the organism of fish has developed in the process of the evolution to survive in changing conditions. Exhaustion of reserves over time due to stress factors may lead to impairments in the physiological processes and death of fish (Adams, 1999; Schultz \& Conover, 1999; Biro et al., 2004; Takegaki \& Takeshita, 2020).

A significant role in the metabolic process belongs to water. It participates in many physical-chemical reactions, the normal functioning of cells and tissues requiring its content to be maintained at stable levels, changes in which may be related to unfavourable conditions (Meyer et al., 1956; Martemyanov, 2013, 2015; Payuta et al., 2019b). There are data reporting inverse relation between the content of lipids and share of water in the organs and tissues of many fish (Bano, 1977; Sutton et al., 2000; Payuta \& Flerova, 2019). The content of lipids and their dynamics in the organism of hydrobionts are important parameters of the condition of both the individuals and their offspring (Adams, 1999; Tocher, 2003; Lloret et al., 2014). Choosing a strategy of distribution and storage of fat reserves allows every species of fish to adapt to the living conditions and successfully compete with other species, for such adaptation is based on energy balance (Adams, 1999; Grande et al., 2016; Murzina et al., 2020). Protein plays an important role in anabolism and energy metabolism. Protein synthesis is associated with processes of growth, fish development, maturation of their sex glands, and its deficiency in the diet reduces or halts the growth and weight gain of fish because of intense expenditure of proteins to support the organism (Bano, 1977; Winfree \& Stickney, 1981; Houlihan et al., 1994; Carter \& Houlihan, 2001). Mineral substances, their ions and compounds are important components of hormones, enzymes and activators of enzymes, and participate in some metabolic processes and are essential in the organism (Lall, 2003; Fawole et al., 2007; Njinkoue et al., 2016). Carbohydrates are the commonest energy source. The resulting energy is used for mechanical work of muscles, biosynthesis, secretory function, and part of it disperses as heat (Shulman \& Love, 1999; Dabrowski \& Guderley, 2003; Lloret et al., 2014).

Data on the peculiarities of the contents of metabolic products in the organism of fish are the basis for understanding the mechanisms of adap- 
tations of individuals to changing environmental conditions. Studying the shifts in the accumulation of metabolic products in the tissues of hydrobionts may be an indicator of the conditions of individual species, fish populations, and also the environment they live in (Shearer, 1994; Ahmed \& Sheikh, 2017; Payuta et al., 2019b).

Over recent years, research has been published on the metabolism of hydrobionts depending on the environmental conditions (Ali et al., 2006; Karamushko, 2016; Payuta et al., 2018; Payuta et al., 2019b). Aside from the environmental factors, the influence of sex, age of individuals, and maturity stage of the gonads on the contents of metabolic products in the organism of fish have been noted (Vdovin \& Antonenko, 2014; Ganguly et al., 2017; Massresha et al., 2017; Mitra et al., 2017; Payuta et al., 2019a; Payuta \& Flerova, 2019). To a greater degree, similar research has been performed on industrial marine fish (Marais \& Venter, 1991; Karakoltsidis et al., 1995; Shulman \& Love, 1999; Amara et al., 2007; Lloret et al., 2014; Gorbatenko \& Lazhentsev, 2016; Cui et al., 2018). However, there are very few studies dealing with a broad spectrum of factors influencing freshwater fish that live in the natural conditions, these studies are scattered and focus on dynamics of individual parameters of metabolism (Jabeen et al., 2015; Tsegay et al., 2016; Payuta et al., 2019a).

The Volga-Caspian Basin is a unique hydrological system that unites water reservoirs different in morphological, morphometric specifics, and anthropogenic impact. Given these specifics, the water reservoirs of the Upper Volga may be a convenient model to study the influence of the aquatic environment on different age and sex groups of fish. Common bream Abramis brama is one of the most abundant species of Cyprinidae family in the water reservoirs of the Volga-Caspian Basin. The species has an important place in the ecosystem of water bodies and is considered an important object of commercial and sport fishing (Subbotkin \& Subbotkina, 2016; Gerasimov et al., 2018; Karabanov et al., 2018). Therefore, study of the content of metabolic products in the muscles and organs of bream that live in the conditions of the water reservoirs of the Upper Volga is of great interest for solving a number of tasks in hydrobiology.

The objective of the study was complex exploration of the influence of the environmental conditions on the parameters of metabolism in the organs and tissues in freshwater fish taking into account sex and age specifics (on the example of bream of the Gorky, Uglich and Ivankovo water reservois).

\section{Materials and methods}

All the procedures with the objects of the study were performed according to the ARRIVE recommendations for using animals in scientific purposes (Kilkenny et al., 2010). All the applicable international, national or institutional instructions on care and use of animals were observed.

The Gorky Reservoir is divided into lake and river parts and is a moderate eutrophic water body. On its right bank, there is one of the largest European and Russian Electric Power Stations - the Kostroma Power Station (Kostromskaya GRES). In the zone of distribution of heated waters, no negative impact on hydrobionts was determined. Surveys of the water body revealed local areas with heightened contents of heavy metals and persistent organic pollutants in water and benthic deposits (Kopylov, 2001; Dzyuban et al., 2007; Perova, 2010; Golovanov, 2013; Mineeva \& Makarova, 2018). The Uglich Reservoir is a eutrophic water body of stream bed type, with high concentrations of heavy metals reported for its water and benthic deposits (Gapeeva \& Zakonnov, 2016; Tolkachev et al., 2017; Mineeva \& Makarova, 2018; Mineeva, 2019).

The Ivankovo Reservoir is a eutrophic water body of valley type with lake-like stream pools characterized by high contents of benthos; pollution in the benthic deposits has been assessed as acceptable. The main source of thermal pollution is the Konakovo Power Station (Konakovskaya GRES), near which there are observed high water temperatures that exceed the norms and negatively affect the development of macrozoobenthos. High temperature is observed $5 \mathrm{~km}$ downstream all across the water (Golovanov, 2013; Tolkachev et al., 2017; Mineeva \& Makarova, 2018; Mineeva, 2019). It has to be noted that in the period of the current study, the Uglich and Ivankovo Reservoirs were characterized by heightened water temperatures and dangerously low concentrations of oxygen for hydrobionts (less than 5 and $2 \mathrm{mg} / \mathrm{L}$ ) (Lazareva et al., 2018a, 2018b;
Mineeva, 2019). Bream were caught from the research vessel Akademik Topchiev during expeditions with the Papanin Institute for Biology of Inland Waters Russian Academy of Sciences. In the Gorky Water Reservoir, the fish of different sexes and ages were collected at the end of the fattening period (September - early October) on standard trawling stations, excluding the material collected in the areas with high degree of pollution (Table 1). In the Uglich and Ivankovo Reservoirs, the bream were caught in August (fattening period) on standard catching stations. The gonads and the liver were extracted from mature specimens.

Table 1

Body size, weight and condition factor of bream $(x \pm S E)$

\begin{tabular}{lrcrccc}
\hline Reservoir & $\mathrm{n}$ & \multicolumn{1}{c}{ Age } & $\begin{array}{c}\text { Length } \\
\text { (SL), cm }\end{array}$ & Weight, g & $\begin{array}{c}\text { Fulton con- } \\
\text { dition factor }\end{array}$ & $\begin{array}{c}\text { Clark con- } \\
\text { dition factor }\end{array}$ \\
\hline Gorky & 104 & $3+-10+$ & $26.7 \pm 0.6$ & $440 \pm 26$ & $2.06 \pm 0.02$ & $1.82 \pm 0.02$ \\
Uglich & 46 & $2+-11+$ & $26.6 \pm 0.9$ & $450 \pm 43$ & $2.06 \pm 0.03$ & $1.86 \pm 0.03$ \\
Ivankovo & 79 & $4+-12+$ & $29.9 \pm 0.8$ & $634 \pm 50$ & $2.20 \pm 0.06$ & $1.95 \pm 0.05$ \\
\hline
\end{tabular}

After catching, the fish were kept in containers with river water, where they underwent acclimatization. We measured standard length (SL), weight of fish, weight of gutted fish, determined sex and stage of maturity of the gonads of each individual. We separated the scales, then the skin from the skeletal muscles, took samples of the muscular tissue from along the cord and extracted the liver and the gonads from the internal cavity. All the samples had been weighed and frozen before the analysis. Age of fish was determined according to the growth zones on the scales. In all the individuals, we identified the indices of physiological condition according to Fulton and Clark.

In the muscular tissue and the organs of fish, we determined the biochemical parameters: content of water, dry mass, fat, protein, ash, carbohydrates in three replications. The concentrations of water and dry matter were determined using two step moisture determination: first the samples were dried in $60^{\circ} \mathrm{C}$ till reaching their constant weight, and then ground in a laboratory mill and dried in the temperature of $105^{\circ} \mathrm{C}$ until the constant weight. Then the concentrations of water and dry matter were calculated using the technique (Flerova, 2014). The number of lipids was calculated according to the method of defatted sediment in Soxhlet apparatus. Extraction was carried out using non-polar solvent - petroleum ether that mostly extracts reserve fats (Parrish, 1999; Min \& Ellefson, 2010; Elliott et al., 2017). Protein content was determined using the Kjeldahl method. Nitrogen content was determined in a semi-hydraulic distiller UDK 139 (Velp Scientifica, Italy, 2011). We multiplied the obtained percentage of nitrogen in the sample by empirical coefficient of protein conversion 6.25 and determined the value of raw protein, which is the total amount of various nitrogen substances based on protein (Chang, 2010; Yeganeh et al., 2012). Ash content was determined using the gravimetric method of burning samples in a muffle furnace at the temperature of $550{ }^{\circ} \mathrm{C}$ (Marshall, 2010; Flerova, 2014).

The data were statistically analyzed in Statistica 10.0 (StatSoft Inc., США, 2011). The data are presented as mean values and their standard errors $(x \pm S E)$. The differences between the values were determined using ANOVA. The differences between the compared parameters were considered significant at $\mathrm{P}<0.05$.

\section{Results}

Mean parameters of fattening and chemical composition of the muscles and the organs of bream. As a result of the study, we determined that the physiological condition indices between bream in the Gorky and Uglich Reservoirs differed insignificantly (Table 1). In bream of the Ivankovo Reservoir, this parameter was higher than in individuals of other water bodies.

On average, the contents of metabolic products in the muscular tissues of bream living in different conditions were similar (Table 2). Nonetheless, compared with the bream from the Uglich and Ivankovo Reservoirs, the individuals from the bream population of the Gorky Reservoir had significantly higher content of dry matter, including proteins and ash, but lower amounts of fat and carbohydrates than the bream of the Uglich Reservoir. The muscular tissue of bream from the Ivankovo Reservoir contained less water compared with bream from the other water bodies. 
Table 2

Biochemical parameters of muscles, liver and gonads of bream $(\mathrm{x} \pm \mathrm{SE})$

\begin{tabular}{|c|c|c|c|c|c|c|c|c|}
\hline \multirow{2}{*}{ Organ / tissue } & \multirow{2}{*}{ Reservoir } & \multirow{2}{*}{$\mathrm{n}$} & \multicolumn{6}{|c|}{ Content, $\%$} \\
\hline & & & water & dry matter & lipids & protein & ash & carbohydrates \\
\hline \multirow{3}{*}{ Muscle } & Gorky & 104 & $78.87 \pm 0.11^{\mathrm{a}}$ & $21.13 \pm 0.11^{\mathrm{a}}$ & $0.97 \pm 0.05^{\mathrm{a}}$ & $17.25 \pm 0.12^{\mathrm{a}}$ & $1.16 \pm 0.02^{\mathrm{a}}$ & $1.75 \pm 0.10^{\mathrm{a}}$ \\
\hline & Uglich & 42 & $80.85 \pm 0.18^{b}$ & $19.15 \pm 0.18^{b}$ & $1.10 \pm 0.05^{\mathrm{a}}$ & $15.37 \pm 0.26^{b}$ & $1.05 \pm 0.03^{\mathrm{b}}$ & $1.85 \pm 0.03^{\mathrm{a}}$ \\
\hline & Ivankovo & 43 & $80.93 \pm 0.21^{\mathrm{b}}$ & $19.07 \pm 0.21^{\mathrm{b}}$ & $1.04 \pm 0.07^{\mathrm{a}}$ & $15.87 \pm 0.23^{\mathrm{b}}$ & $1.11 \pm 0.04^{\mathrm{ab}}$ & $1.05 \pm 0.12^{\mathrm{b}}$ \\
\hline \multirow{3}{*}{ Liver } & Gorky & 84 & $79.56 \pm 0.46^{\mathrm{a}}$ & $20.44 \pm 0.46^{\mathrm{a}}$ & $4.30 \pm 0.44^{\mathrm{a}}$ & $8.56 \pm 0.26^{\mathrm{a}}$ & $0.77 \pm 0.06^{\mathrm{a}}$ & $6.81 \pm 0.32^{\mathrm{a}}$ \\
\hline & Uglich & 46 & $81.22 \pm 0.53^{\mathrm{a}}$ & $17.87 \pm 0.53^{\mathrm{a}}$ & $6.43 \pm 0.48^{\mathrm{b}}$ & $8.49 \pm 0.16^{\mathrm{a}}$ & $0.75 \pm 0.03^{\mathrm{a}}$ & $3.11 \pm 0.14^{b}$ \\
\hline & Ivankovo & 79 & $83.24 \pm 0.51^{b}$ & $16.76 \pm 0.51^{b}$ & $4.90 \pm 0.30^{\mathrm{a}}$ & $7.93 \pm 0.21^{\mathrm{a}}$ & $0.74 \pm 0.03^{\mathrm{a}}$ & $3.19 \pm 0.13^{\mathrm{b}}$ \\
\hline \multirow{3}{*}{ Testes* } & Gorky & 33 & $66.37 \pm 2.60^{\mathrm{a}}$ & $33.63 \pm 2.60^{\mathrm{a}}$ & $24.43 \pm 2.94^{\mathrm{a}}$ & $5.06 \pm 0.51^{\mathrm{a}}$ & $0.73 \pm 0.19^{\mathrm{a}}$ & $3.40 \pm 0.56^{\mathrm{a}}$ \\
\hline & Uglich & 16 & $68.07 \pm 1.64^{\mathrm{a}}$ & $31.93 \pm 1.64^{\mathrm{a}}$ & $18.00 \pm 2.18^{\mathrm{a}}$ & $8.57 \pm 1.52^{\mathrm{b}}$ & $1.26 \pm 0.21^{\mathrm{a}}$ & $4.09 \pm 1.29^{\mathrm{a}}$ \\
\hline & Ivankovo & 16 & $66.33 \pm 3.46^{\mathrm{a}}$ & $33.67 \pm 3.46^{\mathrm{a}}$ & $22.16 \pm 3.05^{\mathrm{a}}$ & $7.80 \pm 0.56^{\mathrm{ab}}$ & $0.95 \pm 0.06^{\mathrm{a}}$ & $2.76 \pm 1.09^{\mathrm{a}}$ \\
\hline \multirow{3}{*}{ Ovaries* } & Gorky & 51 & $71.45 \pm 2.71^{\mathrm{a}}$ & $28.55 \pm 2.71^{\mathrm{a}}$ & $15.35 \pm 2.96^{\mathrm{a}}$ & $8.54 \pm 0.63^{\mathrm{a}}$ & $1.21 \pm 0.31^{\mathrm{a}}$ & $3.45 \pm 0.73^{\mathrm{a}}$ \\
\hline & Uglich & 27 & $76.75 \pm 0.79^{\mathrm{a}}$ & $23.25 \pm 0.79^{\mathrm{a}}$ & $5.21 \pm 0.64^{\mathrm{b}}$ & $14.21 \pm 0.64^{\mathrm{b}}$ & $0.90 \pm 0.09^{\mathrm{a}}$ & $2.93 \pm 0.39^{\mathrm{a}}$ \\
\hline & Ivankovo & 59 & $73.24 \pm 1.20^{\mathrm{a}}$ & $26.76 \pm 1.20^{\mathrm{a}}$ & $11.36 \pm 1.13^{\mathrm{a}}$ & $12.12 \pm 0.47^{\mathrm{c}}$ & $1.22 \pm 0.09^{\mathrm{a}}$ & $2.07 \pm 0.36^{\mathrm{a}}$ \\
\hline
\end{tabular}

Note: gonads of fish at maturity stages II and III; different letters in the column indicate values that significantly differ one from another between the reservoirs separately for the muscular tissue, liver and gonads of males and females using Bonferroni correction $(\mathrm{P}<0.05)$.

In the liver of bream of the Ivankovo Reservoir, there was statistically greater concentration of water, whereas the individuals of the Uglich Reservoir had more lipids and those of the Gorky Reservoir - carbohydrates. The gonads of male and female bream of the Gorky Reservoir contained the largest amount of lipids, while having the lowest content of protein. Bream of the Uglich Reservoir had more ash and carbohydrates in the testes than males of the examined water bodies had in the gonads. The sex glands of females from the Gorky Reservoirs were characterized by heightened concentration of carbohydrates, and the gonads of females of the Ivankovo Reservoir - increased content of mineral substances.

Chemical composition of the muscles and organs of bream of different sexes and maturity stages of the gonads. Content of dry matter and fat in the muscles of bream of the Gorky Reservoir decreased as follows: males - females - juveniles. The highest content of protein was found in the muscular tissue of immature bream, the lowest - in the muscles of males. The level of ash accumulation decreased in the following order: males - juveniles - females; the descending order of the content of carbohydrates was as follows: males - females - juveniles (Table 3).

The liver of male bream of the Gorky Reservoir contained more dry matter, including protein, ash and carbohydrates, than females. Content of fat in the liver of both sexes was similar. The ovaries of bream of the
Gorky Reservoir had lower concentrations of dry matter and fat, but significantly greater amounts of protein and mineral compounds (Table 3 ).

In both the ovaries and testes of bream of the Gorky Reservoir, the content of dry matter, lipids decreased and those of water and carbohydrates increased with maturity. During the maturation, the content of protein and ash in the gonads of male bream increased, by contrast to the reproductive organs of females, where the analyzed parameters decreased as the gonads maturated (Table 4).

The concentrations of dry matter and protein in the muscles of bream of the Uglich Reservoir increased in the following order: males - juveniles females. Lower content of fat was seen in the muscles of males and juveniles as compared with females. The content of ash increased in following order: immature individuals - males - females. The highest content of carbohydrates was seen in the muscles of males, while the lowest was observed in females of the Uglich Reservoir (Table 5).

In the liver of female bream of the Uglich Reservoir, we found heightened contents of dry matter, fat, carbohydrates and decreased amounts of protein and ash compared with females. The testes of bream of the Uglich Reservoir contained statistically significantly greater amounts of dry matter and fat and lower content of protein compared with the ovaries (Table 5).

Table 3

Biochemical indicators of muscles, liver and gonads of bream, differing in sex, from the Gorky Reservoir $(\mathrm{x} \pm \mathrm{SE})$

\begin{tabular}{|c|c|c|c|c|c|c|c|c|}
\hline \multirow{2}{*}{ Organ/tissue } & \multirow{2}{*}{ Sex } & \multirow{2}{*}{$\mathrm{n}$} & \multicolumn{6}{|c|}{ Content, \% } \\
\hline & & & water & dry matter & lipids & protein & ash & carbohydrates \\
\hline \multirow{3}{*}{ Muscle } & Males & 33 & $78.82 \pm 0.15$ & $21.18 \pm 0.15$ & $1.07 \pm 0.09$ & $17.04 \pm 0.20$ & $1.23 \pm 0.05$ & $1.84 \pm 0.22$ \\
\hline & Females & 51 & $78.87 \pm 0.19$ & $21.13 \pm 0.19$ & $0.97 \pm 0.08$ & $17.33 \pm 0.18$ & $1.09 \pm 0.03^{*}$ & $1.74 \pm 0.13$ \\
\hline & Juveniles & 20 & $78.95 \pm 0.17$ & $21.05 \pm 0.17$ & $0.82 \pm 0.07$ & $17.38 \pm 0.20$ & $1.17 \pm 0.04$ & $1.68 \pm 0.18$ \\
\hline \multirow{2}{*}{ Liver } & Males & 33 & $80.03 \pm 2.19$ & $19.97 \pm 2.19$ & $4.73 \pm 2.22$ & $7.96 \pm 0.67$ & $0.74 \pm 0.15$ & $6.54 \pm 0.53$ \\
\hline & Females & 51 & $79.08 \pm 2.09$ & $20.92 \pm 2.09$ & $4.73 \pm 0.94$ & $8.69 \pm 0.81$ & $0.89 \pm 0.22$ & $6.61 \pm 0.91$ \\
\hline \multirow{2}{*}{ Gonads } & Males & 33 & $65.24 \pm 2.89$ & $34.76 \pm 2.89$ & $25.62 \pm 3.29$ & $5.15 \pm 0.59$ & $0.48 \pm 0.08$ & $3.51 \pm 0.68$ \\
\hline & Females & 51 & $69.43 \pm 2.50$ & $30.57 \pm 2.50$ & $17.17 \pm 3.15$ & $8.93 \pm 0.64^{*}$ & $0.80 \pm 0.09 *$ & $3.67 \pm 0.91$ \\
\hline
\end{tabular}

Note: index * in the column indicates values that are significantly different from males separately for the muscles, liver and gonads, taking into account Bonferroni correction $(\mathrm{P}<0.05)$.

Table 4

Biochemical parameters of bream gonads, differing in maturity stage, from reservoirs of the Upper Volga $(x \pm S E)$

\begin{tabular}{|c|c|c|c|c|c|c|c|c|}
\hline \multirow{2}{*}{ Reservoir } & \multirow{2}{*}{$\begin{array}{c}\text { Sex, gonad } \\
\text { maturation stage }\end{array}$} & \multirow{2}{*}{$\mathrm{n}$} & \multicolumn{6}{|c|}{ Content, $\%$} \\
\hline & & & water & dry matter & lipids & protein & ash & carbohydrates \\
\hline \multirow{4}{*}{ Gorky } & Males, II & 26 & $60.95 \pm 3.88$ & $39.05 \pm 3.88$ & $31.60 \pm 3.76$ & $4.49 \pm 0.71$ & $0.32 \pm 0.08$ & $2.64 \pm 0.90$ \\
\hline & Males, III & 7 & $72.11 \pm 2.24 *$ & $27.89 \pm 2.24 *$ & $16.05 \pm 2.74 *$ & $6.21 \pm 0.99$ & $0.74 \pm 0.07 *$ & $4.89 \pm 0.86$ \\
\hline & Females, II & 47 & $69.29 \pm 3.05$ & $30.71 \pm 3.05$ & $17.67 \pm 3.81$ & $9.23 \pm 0.74$ & $0.86 \pm 0.09$ & $2.95 \pm 0.80$ \\
\hline & Females, III & 4 & $70.17 \pm 2.08$ & $29.83 \pm 2.08$ & $14.65 \pm 2.90$ & $7.47 \pm 0.58$ & $0.47 \pm 0.26$ & $7.24 \pm 4.14$ \\
\hline \multirow{4}{*}{ Uglich } & Males, II & 10 & $66.63 \pm 1.55$ & $33.37 \pm 1.55$ & $21.69 \pm 0.98$ & $5.77 \pm 0.18$ & $0.93 \pm 0.04$ & $4.99 \pm 1.79$ \\
\hline & Males, III & 6 & $68.14 \pm 3.35$ & $31.86 \pm 3.35$ & $17.38 \pm 4.23$ & $8.74 \pm 2.78$ & $1.03 \pm 0.19$ & $4.72 \pm 2.12$ \\
\hline & Females, II & 14 & $75.49 \pm 0.12$ & $24.51 \pm 0.12$ & $8.06 \pm 1.11$ & $12.42 \pm 0.87$ & $0.97 \pm 0.11$ & $3.05 \pm 0.86$ \\
\hline & Females, III & 13 & $77.63 \pm 1.10$ & $22.37 \pm 1.10$ & $3.22 \pm 0.37 *$ & $15.46 \pm 0.81 *$ & $0.85 \pm 0.14$ & $2.84 \pm 0.32$ \\
\hline \multirow{4}{*}{ Ivankovo } & Males, II & 8 & $65.77 \pm 3.37$ & $34.23 \pm 3.37$ & $22.64 \pm 2.52$ & $8.22 \pm 0.34$ & $1.04 \pm 0.14$ & $2.34 \pm 0.98$ \\
\hline & Males, III & 8 & $66.71 \pm 5.88$ & $33.29 \pm 5.88$ & $21.84 \pm 5.26$ & $7.52 \pm 0.96$ & $0.90 \pm 0.06$ & $3.04 \pm 1.86$ \\
\hline & Females, II & 20 & $71.57 \pm 1.17$ & $28.43 \pm 1.17$ & $14.26 \pm 1.41$ & $11.22 \pm 0.46$ & $1.07 \pm 0.14$ & $1.89 \pm 0.46$ \\
\hline & Females, III & 39 & $74.35 \pm 1.88$ & $25.65 \pm 1.88$ & $9.42 \pm 1.59 *$ & $12.72 \pm 0.72$ & $1.31 \pm 0.13$ & $2.19 \pm 0.54$ \\
\hline
\end{tabular}

Note: index * in the column indicates values that significantly differ from maturity stage II of the gonads separately for males and females of one reservoir taking into account Bonferroni correction $(\mathrm{P}<0.05)$. 
Table 5

Biochemical indicators of muscles, liver and gonads of bream, differing in sex, from the Uglich Reservoir $(\mathrm{x} \pm \mathrm{SE})$

\begin{tabular}{|c|c|c|c|c|c|c|c|c|}
\hline \multirow{2}{*}{ Organ / tissue } & \multirow{2}{*}{ Sex } & \multirow{2}{*}{$\mathrm{n}$} & \multicolumn{6}{|c|}{ Content, \% } \\
\hline & & & water & dry matter & lipids & protein & ash & carbohydrates \\
\hline \multirow{3}{*}{ Muscle } & Males & 13 & $81.24 \pm 0.16$ & $18.76 \pm 0.16$ & $1.05 \pm 0.11$ & $14.88 \pm 0.39$ & $1.00 \pm 0.04$ & $1.84 \pm 0.42$ \\
\hline & Females & 21 & $80.54 \pm 0.33$ & $19.46 \pm 0.33$ & $1.16 \pm 0.07$ & $15.64 \pm 0.42$ & $1.16 \pm 0.04 *$ & $1.51 \pm 0.25$ \\
\hline & Juveniles & 8 & $81.04 \pm 0.22$ & $18.96 \pm 0.22$ & $1.05 \pm 0.05$ & $15.48 \pm 0.38$ & $0.86 \pm 0.04^{\mathrm{f}}$ & $1.57 \pm 0.30$ \\
\hline \multirow{2}{*}{ Liver } & Males & 16 & $80.41 \pm 0.94$ & $19.59 \pm 0.94$ & $7.04 \pm 1.18$ & $8.23 \pm 0.27$ & $0.74 \pm 0.06$ & $3.58 \pm 0.40$ \\
\hline & Females & 27 & $81.13 \pm 0.74$ & $18.87 \pm 0.74$ & $6.50 \pm 0.62$ & $8.64 \pm 0.23$ & $0.76 \pm 0.05$ & $2.97 \pm 0.16$ \\
\hline \multirow{2}{*}{ Gonads } & Males & 16 & $68.07 \pm 1.64$ & $31.93 \pm 1.64$ & $18.00 \pm 2.18$ & $8.57 \pm 1.52$ & $1.26 \pm 0.21$ & $4.09 \pm 1.29$ \\
\hline & Females & 27 & $76.75 \pm 0.79^{*}$ & $23.25 \pm 0.79 *$ & $5.21 \pm 0.64 *$ & $14.21 \pm 0.64 *$ & $0.90 \pm 0.09$ & $2.93 \pm 0.39$ \\
\hline
\end{tabular}

Note: index * in the column indicates values that are significantly different from males, $f$-from females separately for the muscles, liver and gonads taking into account Bonferroni correction $(\mathrm{P}<0.05)$.

The more mature the gonads of males and females, the lower the amounts of dry matter, fat, carbohydrates and higher content of protein they had. The ash content in males increased, while that of females decreased. The dynamics of the amounts of lipids and protein in females was statistically significant (Table 4).

Male bream of the Ivankovo Reservoirs had greater content of lipids of carbohydrates in the muscular tissues than the females did, but had lower contents of dry matter, protein and ash (Table 6).
In the liver of female bream, there were more fat and mineral substances, but less proteins and carbohydrates than in males. In the testes of bream, the content of protein was significantly higher, and amounts of dry matter and lipids were lower than in the ovaries (Table 6).

During maturation, in the gonads of male and female bream of the Ivankovo Reservoir, the content of dry matter and fat decreased, while the share of carbohydrates increased. In the testes, the amount of protein and ash decreased with maturation, while in the ovaries it increased (Table 4).

Table 6

Biochemical indicators of muscles, liver and gonads of bream, differing in sex, from the Ivankovo Reservoir $(x \pm S E)$

\begin{tabular}{|c|c|c|c|c|c|c|c|c|}
\hline \multirow{2}{*}{ Organ / tissue } & \multirow{2}{*}{ Sex } & \multirow{2}{*}{$\mathrm{n}$} & \multicolumn{6}{|c|}{ Content, $\%$} \\
\hline & & & water & dry matter & lipids & protein & ash & carbohydrates \\
\hline \multirow{2}{*}{ Muscle } & Males & 12 & $81.20 \pm 0.39$ & $18.80 \pm 0.39$ & $1.14 \pm 0.15$ & $15.28 \pm 0.52$ & $1.05 \pm 0.06$ & $1.33 \pm 0.35$ \\
\hline & Females & 31 & $80.83 \pm 0.25$ & $19.17 \pm 0.25$ & $1.00 \pm 0.08$ & $16.10 \pm 0.24$ & $1.13 \pm 0.05$ & $0.94 \pm 0.11$ \\
\hline \multirow{2}{*}{ Liver } & Males & 16 & $82.54 \pm 0.50$ & $17.46 \pm 0.50$ & $4.77 \pm 0.47$ & $8.27 \pm 0.39$ & $0.68 \pm 0.02$ & $3.73 \pm 0.19$ \\
\hline & Females & 59 & $83.37 \pm 0.75$ & $16.63 \pm 0.75$ & $5.21 \pm 0.41$ & $7.66 \pm 0.27$ & $0.72 \pm 0.03$ & $3.04 \pm 0.17^{*}$ \\
\hline \multirow{2}{*}{ Gonads } & Males & 16 & $66.33 \pm 3.46$ & $33.67 \pm 3.46$ & $22.16 \pm 3.05$ & $7.80 \pm 0.56$ & $0.95 \pm 0.06$ & $2.76 \pm 1.09$ \\
\hline & Females & 59 & $73.24 \pm 1.20^{*}$ & $26.76 \pm 1.20 *$ & $11.36 \pm 1.13^{*}$ & $12.12 \pm 0.47 *$ & $1.22 \pm 0.09$ & $2.07 \pm 0.36$ \\
\hline
\end{tabular}

Note: index * in the line indicates the values significantly different from the males separately for the muscles, liver and the gonads taking into account Bonferroni correction $(\mathrm{P}<0.05)$.

Chemical composition of bream individuals of different age and water bodies. The content of dry matter and fat in the muscles of bream of the Gorky Reservoir had an increasing trend with age (Table 7). Minimum amount of protein was found in three-year old bream, further increasing. Ash content changed insignificantly with a tendency towards increase. The amount of carbohydrates in the muscles was characterized by decreasing trend.
In the liver of bream from the Gorky Reservoir, we found no significant changes in the amounts of water and dry matter with age. We determined age-related increase in fat reserves, the protein component had increased in the period from $6+$ to $8+$, and then dropped to minimum at $10+$. Content of mineral substances insignificantly changed at the age from $6+$ to $8+$, and at $9+$ decreased almost 2 -fold. Share of carbohydrates changed insignificantly with age, having a tendency towards decrease (Table 7).

Table 7

Biochemical parameters of muscles, liver and gonads of bream of different ages from the Gorky Reservoir $(x \pm \mathrm{SE})$

\begin{tabular}{|c|c|c|c|c|c|c|c|c|}
\hline \multirow{2}{*}{ Organ / tissue } & \multirow{2}{*}{ Age } & \multirow{2}{*}{$\mathrm{n}$} & \multicolumn{6}{|c|}{ Content, $\%$} \\
\hline & & & water & dry matter & lipids & protein & ash & carbohydrates \\
\hline \multirow{8}{*}{ Muscle } & $3+$ & 3 & $80.42 \pm 0.83^{\mathrm{a}}$ & $19.58 \pm 0.83^{\mathrm{a}}$ & $0.79 \pm 0.07^{\mathrm{ac}}$ & $15.38 \pm 0.89^{\mathrm{a}}$ & $1.01 \pm 0.10^{\mathrm{a}}$ & $2.39 \pm 0.92^{\mathrm{a}}$ \\
\hline & $4+$ & 30 & $79.15 \pm 0.14^{\mathrm{ab}}$ & $20.85 \pm 0.14^{\mathrm{ab}}$ & $0.76 \pm 0.04^{\mathrm{a}}$ & $17.15 \pm 0.13^{\mathrm{ab}}$ & $1.16 \pm 0.05^{\mathrm{a}}$ & $1.78 \pm 0.13^{\mathrm{a}}$ \\
\hline & $5+$ & 15 & $79.14 \pm 0.14^{\mathrm{ab}}$ & $20.86 \pm 0.14^{\mathrm{ab}}$ & $0.79 \pm 0.07^{\mathrm{ac}}$ & $16.86 \pm 0.32^{\mathrm{ab}}$ & $1.11 \pm 0.11^{\mathrm{a}}$ & $2.09 \pm 0.27^{\mathrm{a}}$ \\
\hline & $6+$ & 10 & $79.22 \pm 0.72^{\mathrm{ab}}$ & $20.78 \pm 0.72^{\mathrm{ab}}$ & $0.74 \pm 0.10^{\mathrm{ac}}$ & $17.60 \pm 0.59^{\mathrm{ab}}$ & $1.12 \pm 0.05^{\mathrm{a}}$ & $1.33 \pm 0.11^{\mathrm{a}}$ \\
\hline & $7+$ & 15 & $78.76 \pm 0.22^{\mathrm{ab}}$ & $21.24 \pm 0.22^{\mathrm{ab}}$ & $0.94 \pm 0.13^{\mathrm{ac}}$ & $17.16 \pm 0.32^{\mathrm{ab}}$ & $1.16 \pm 0.06^{\mathrm{a}}$ & $1.97 \pm 0.37^{\mathrm{a}}$ \\
\hline & $8+$ & 10 & $78.31 \pm 0.31^{\mathrm{ab}}$ & $21.69 \pm 0.31^{\mathrm{ab}}$ & $1.16 \pm 0.19^{\mathrm{abc}}$ & $17.52 \pm 0.45^{\mathrm{ab}}$ & $1.12 \pm 0.06^{\mathrm{a}}$ & $1.88 \pm 0.46^{\mathrm{a}}$ \\
\hline & $9+$ & 11 & $78.47 \pm 0.28^{\mathrm{ab}}$ & $21.53 \pm 0.28^{\mathrm{ab}}$ & $1.25 \pm 0.20^{\mathrm{bc}}$ & $17.57 \pm 0.31^{\mathrm{ab}}$ & $1.18 \pm 0.05^{\mathrm{a}}$ & $1.53 \pm 0.35^{\mathrm{a}}$ \\
\hline & $10+$ & 10 & $77.99 \pm 0.45^{\mathrm{b}}$ & $22.01 \pm 0.45^{\mathrm{b}}$ & $1.72 \pm 0.17^{\mathrm{b}}$ & $17.83 \pm 0.37^{\mathrm{b}}$ & $1.22 \pm 0.07^{\mathrm{a}}$ & $1.25 \pm 0.30^{\mathrm{a}}$ \\
\hline \multirow{5}{*}{ Liver } & $6+$ & 9 & $79.51 \pm 0.18^{\mathrm{a}}$ & $20.49 \pm 0.18^{\mathrm{a}}$ & $1.75 \pm 0.18^{\mathrm{a}}$ & $8.62 \pm 0.04^{\mathrm{a}}$ & $0.97 \pm 0.20^{\mathrm{a}}$ & $9.15 \pm 0.24^{\mathrm{a}}$ \\
\hline & $7+$ & 14 & $78.98 \pm 0.76^{\mathrm{a}}$ & $21.02 \pm 0.76^{\mathrm{a}}$ & $3.74 \pm 0.51^{\mathrm{a}}$ & $9.82 \pm 0.74^{\mathrm{a}}$ & $0.95 \pm 0.09^{\mathrm{a}}$ & $6.51 \pm 0.78^{\mathrm{ab}}$ \\
\hline & $8+$ & 9 & $79.02 \pm 1.27^{\mathrm{a}}$ & $20.98 \pm 1.27^{\mathrm{a}}$ & $4.16 \pm 0.74^{\mathrm{a}}$ & $9.33 \pm 0.14^{\mathrm{a}}$ & $0.97 \pm 0.11^{\mathrm{a}}$ & $6.52 \pm 0.49^{b}$ \\
\hline & $9+$ & 11 & $79.33 \pm 1.12^{\mathrm{a}}$ & $20.67 \pm 1.12^{\mathrm{a}}$ & $4.70 \pm 1.15^{\mathrm{a}}$ & $8.00 \pm 0.53^{\mathrm{a}}$ & $0.54 \pm 0.13^{\mathrm{a}}$ & $7.43 \pm 0.38^{\mathrm{ab}}$ \\
\hline & $10+$ & 10 & $80.11 \pm 2.21^{\mathrm{a}}$ & $19.89 \pm 2.21^{\mathrm{a}}$ & $5.18 \pm 1.98^{\mathrm{a}}$ & $7.81 \pm 0.51^{\mathrm{a}}$ & $0.61 \pm 0.03^{\mathrm{a}}$ & $6.29 \pm 0.62^{\mathrm{b}}$ \\
\hline \multirow{5}{*}{ Testes } & $6+$ & 3 & $61.86 \pm 0.52^{\mathrm{a}}$ & $38.14 \pm 0.52^{\mathrm{a}}$ & $31.05 \pm 2.20^{\mathrm{a}}$ & $6.10 \pm 0.40^{\mathrm{a}}$ & $0.51 \pm 0.25^{\mathrm{a}}$ & $0.48 \pm 0.07^{\mathrm{a}}$ \\
\hline & $7+$ & 4 & $54.17 \pm 1.06^{\mathrm{a}}$ & $45.83 \pm 1.06^{\mathrm{a}}$ & $37.54 \pm 2.47^{\mathrm{a}}$ & $3.29 \pm 0.93^{\mathrm{a}}$ & $0.16 \pm 0.02^{\mathrm{a}}$ & $4.84 \pm 2.32^{\mathrm{a}}$ \\
\hline & $8+$ & 5 & $67.60 \pm 6.08^{\mathrm{a}}$ & $32.40 \pm 6.08^{\mathrm{a}}$ & $24.08 \pm 6.44^{\mathrm{a}}$ & $4.15 \pm 1.17^{\mathrm{a}}$ & $0.32 \pm 0.15^{\mathrm{a}}$ & $3.85 \pm 1.55^{\mathrm{a}}$ \\
\hline & $9+$ & 4 & $64.00 \pm 11.04^{\mathrm{a}}$ & $36.00 \pm 11.04^{\mathrm{a}}$ & $25.26 \pm 13.01^{\mathrm{a}}$ & $5.98 \pm 2.30^{\mathrm{a}}$ & $0.61 \pm 0.27^{\mathrm{a}}$ & $4.15 \pm 1.43^{\mathrm{a}}$ \\
\hline & $10+$ & 6 & $73.76 \pm 3.80^{\mathrm{a}}$ & $26.24 \pm 3.80^{\mathrm{a}}$ & $15.95 \pm 4.19^{\mathrm{a}}$ & $5.96 \pm 1.22^{\mathrm{a}}$ & $0.71 \pm 0.05^{\mathrm{a}}$ & $3.62 \pm 1.85^{\mathrm{a}}$ \\
\hline \multirow{5}{*}{ Ovaries } & $6+$ & 7 & $79.44 \pm 0.36^{\mathrm{a}}$ & $20.56 \pm 0.36^{\mathrm{a}}$ & $2.39 \pm 1.07^{\mathrm{a}}$ & $11.94 \pm 0.18^{\mathrm{a}}$ & $1.02 \pm 0.42^{\mathrm{a}}$ & $5.21 \pm 1.19^{\mathrm{a}}$ \\
\hline & $7+$ & 9 & $63.72 \pm 0.18^{\mathrm{a}}$ & $36.28 \pm 0.18^{\mathrm{a}}$ & $22.02 \pm 4.05^{\mathrm{a}}$ & $11.00 \pm 0.71^{\mathrm{a}}$ & $0.61 \pm 0.10^{\mathrm{a}}$ & $2.65 \pm 2.03^{\mathrm{a}}$ \\
\hline & $8+$ & 4 & $62.87 \pm 5.80^{\mathrm{a}}$ & $37.13 \pm 5.80^{\mathrm{a}}$ & $23.27 \pm 8.43^{\mathrm{a}}$ & $7.96 \pm 0.27^{\mathrm{a}}$ & $0.68 \pm 0.12^{\mathrm{a}}$ & $5.22 \pm 3.10^{\mathrm{a}}$ \\
\hline & $9+$ & 7 & $68.44 \pm 5.64^{\mathrm{a}}$ & $31.56 \pm 5.64^{\mathrm{a}}$ & $21.14 \pm 7.02^{\mathrm{a}}$ & $7.73 \pm 1.47^{\mathrm{a}}$ & $0.73 \pm 0.28^{\mathrm{a}}$ & $1.96 \pm 1.47^{\mathrm{a}}$ \\
\hline & $10+$ & 4 & $76.46 \pm 0.01^{\mathrm{a}}$ & $23.54 \pm 0.01^{\mathrm{a}}$ & $12.00 \pm 2.38^{\mathrm{a}}$ & $7.13 \pm 0.71^{\mathrm{a}}$ & $1.06 \pm 0.12^{\mathrm{a}}$ & $3.35 \pm 1.78^{\mathrm{a}}$ \\
\hline
\end{tabular}

Note: different letters in the column indicate values that significantly differ one from another between individuals of different age separately for the muscular tissue, liver, testes and ovaries taking into account Bonferroni correction $(\mathrm{P}<0.05)$. 
In the testes of bream of the Gorky Reservoir, the content of water had an increasing trend and fat had a decreasing trend. The amount of protein changed unequally within $3.29-6.10 \%$. Decrease in ash content at the age from $6+$ to $7+$ was followed by increase. Concentration of carbohydrates increased 10 -fold at the age of $7+$, and then changed insignificantly (Table 7).

In the gonads of females, the amount of water decreased till the age of $8+$, and then increased. After increase in fat level in the period from $6+$ to $8+$, it decreased by almost two times at the age of $10+$. Content of protein in the ovaries had a decreasing trend. Ash content decreased till the age
$7+$, and then increased, whereas age-related changes in the dynamics of content of carbohydrates manifested poorly (Table 7).

Age dynamics of the water content in the muscles of bream of the Uglich Reservoir was characterized by a tendency towards decrease (Table 8). The amount of lipids with age changed inequally. Till the age of $7+$, we observed alternation of positive and negative shifts in the protein content, and then this parameter peaked at the age of 11 years. Maximum content of mineral substances was found at the age of 11+, and the lowest - in young individuals. The amount of carbohydrates with age had a descending trend, the highest values occurring at the age of $5+$ and $7+$.

Table 8

Biochemical parameters of muscles, liver and gonads of bream of different ages from the Uglich Reservoir $(\mathrm{x} \pm \mathrm{SE})$

\begin{tabular}{|c|c|c|c|c|c|c|c|c|}
\hline \multirow{2}{*}{ Organ / tissue } & \multirow{2}{*}{ Age } & \multirow{2}{*}{$\mathrm{n}$} & \multicolumn{6}{|c|}{ Content, \% } \\
\hline & & & water & dry matter & lipids & protein & ash & carbohydrates \\
\hline \multirow{8}{*}{ Muscle } & $2+$ & 4 & $81.11 \pm 0.28^{\mathrm{a}}$ & $18.89 \pm 0.28^{\mathrm{a}}$ & $1.09 \pm 0.03^{\mathrm{ab}}$ & $14.85 \pm 0.52^{\mathrm{a}}$ & $0.86 \pm 0.06^{\mathrm{a}}$ & $2.10 \pm 0.40^{\mathrm{a}}$ \\
\hline & $3+$ & 4 & $80.98 \pm 0.44^{\mathrm{a}}$ & $19.02 \pm 0.44^{\mathrm{a}}$ & $1.00 \pm 0.10^{\mathrm{ab}}$ & $16.11 \pm 0.38^{\mathrm{ab}}$ & $0.86 \pm 0.07^{\mathrm{a}}$ & $1.05 \pm 0.27^{\mathrm{a}}$ \\
\hline & $5+$ & 5 & $81.56 \pm 0.56^{\mathrm{a}}$ & $18.44 \pm 0.56^{\mathrm{a}}$ & $1.18 \pm 0.04^{\mathrm{ab}}$ & $13.63 \pm 0.90^{\mathrm{a}}$ & $0.93 \pm 0.06^{\mathrm{ab}}$ & $2.70 \pm 1.32^{\mathrm{a}}$ \\
\hline & $6+$ & 5 & $81.60 \pm 0.15^{\mathrm{a}}$ & $18.40 \pm 0.15^{\mathrm{a}}$ & $0.92 \pm 0.08^{\mathrm{ab}}$ & $15.49 \pm 0.31^{\mathrm{a}}$ & $0.91 \pm 0.03^{\mathrm{ab}}$ & $1.08 \pm 0.40^{\mathrm{a}}$ \\
\hline & $7+$ & 8 & $81.08 \pm 0.26^{\mathrm{a}}$ & $18.92 \pm 0.26^{\mathrm{a}}$ & $1.14 \pm 0.09^{\mathrm{ab}}$ & $14.39 \pm 0.48^{\mathrm{a}}$ & $1.18 \pm 0.04^{b}$ & $2.21 \pm 0.50^{\mathrm{a}}$ \\
\hline & $8+$ & 10 & $81.01 \pm 0.15^{\mathrm{a}}$ & $18.99 \pm 0.15^{\mathrm{a}}$ & $1.22 \pm 0.09^{\mathrm{a}}$ & $14.86 \pm 0.47^{\mathrm{a}}$ & $1.10 \pm 0.03^{\mathrm{ab}}$ & $1.81 \pm 0.44^{\mathrm{a}}$ \\
\hline & $9+$ & 3 & $81.19 \pm 0.66^{\mathrm{a}}$ & $18.81 \pm 0.66^{\mathrm{a}}$ & $0.64 \pm 0.17^{\mathrm{b}}$ & $16.50 \pm 0.60^{\mathrm{ab}}$ & $0.94 \pm 0.11^{\mathrm{ab}}$ & $0.73 \pm 0.19^{\mathrm{a}}$ \\
\hline & $11+$ & 3 & $77.93 \pm 0.76^{b}$ & $22.07 \pm 0.76^{\mathrm{b}}$ & $1.39 \pm 0.36^{\mathrm{a}}$ & $18.61 \pm 0.24^{\mathrm{b}}$ & $1.39 \pm 0.19^{c}$ & $0.68 \pm 0.07^{\mathrm{a}}$ \\
\hline \multirow{6}{*}{ Liver } & $6+$ & 5 & $82.15 \pm 0.05^{\mathrm{ab}}$ & $17.85 \pm 0.05^{\mathrm{ab}}$ & $5.59 \pm 0.22^{\mathrm{ab}}$ & $8.24 \pm 0.38^{\mathrm{ab}}$ & $0.65 \pm 0.01^{\mathrm{a}}$ & $3.38 \pm 0.20^{\mathrm{a}}$ \\
\hline & $7+$ & 8 & $83.22 \pm 0.76^{\mathrm{a}}$ & $16.78 \pm 0.76^{\mathrm{a}}$ & $5.19 \pm 0.46^{\mathrm{ab}}$ & $7.90 \pm 0.22^{\mathrm{a}}$ & $0.69 \pm 0.04^{\mathrm{a}}$ & $3.01 \pm 0.28^{\mathrm{a}}$ \\
\hline & $8+$ & 17 & $82.58 \pm 0.54^{\mathrm{a}}$ & $17.42 \pm 0.54^{\mathrm{a}}$ & $5.13 \pm 0.37^{\mathrm{a}}$ & $7.98 \pm 0.23^{\mathrm{a}}$ & $070 \pm 0.05^{\mathrm{a}}$ & $3.61 \pm 0.61^{\mathrm{a}}$ \\
\hline & $9+$ & 7 & $77.59 \pm 0.54^{\mathrm{b}}$ & $22.41 \pm 0.54^{\mathrm{b}}$ & $9.37 \pm 0.91^{\mathrm{b}}$ & $9.53 \pm 0.46^{\mathrm{b}}$ & $0.87 \pm 0.11^{\mathrm{a}}$ & $2.64 \pm 0.39^{\mathrm{a}}$ \\
\hline & $10+$ & 6 & $80.32 \pm 2.08^{\mathrm{ab}}$ & $19.68 \pm 2.08^{\mathrm{ab}}$ & $7.44 \pm 1.98^{\mathrm{ab}}$ & $8.82 \pm 0.24^{\mathrm{ab}}$ & $0.78 \pm 0.10^{\mathrm{a}}$ & $2.63 \pm 0.21^{\mathrm{a}}$ \\
\hline & $11+$ & 3 & $82.11 \pm 0.13^{\mathrm{ab}}$ & $17.89 \pm 0.13^{\mathrm{ab}}$ & $5.32 \pm 0.24^{\mathrm{ab}}$ & $8.66 \pm 0.31^{\mathrm{ab}}$ & $0.81 \pm 0.15^{\mathrm{a}}$ & $3.11 \pm 0.27^{\mathrm{a}}$ \\
\hline \multirow{2}{*}{ Testes } & $8+$ & 13 & $65.88 \pm 2.01^{\mathrm{a}}$ & $34.12 \pm 2.01^{\mathrm{a}}$ & $22.30 \pm 1.38^{\mathrm{a}}$ & $5.30 \pm 0.41^{\mathrm{a}}$ & $0.94 \pm 0.13^{\mathrm{a}}$ & $5.59 \pm 1.52^{\mathrm{a}}$ \\
\hline & $9+$ & 3 & $72.46 \pm 1.13^{\mathrm{b}}$ & $27.54 \pm 1.13^{\mathrm{b}}$ & $9.42 \pm 2.07^{\mathrm{b}}$ & $15.13 \pm 1.15^{\mathrm{b}}$ & $1.90 \pm 0.48^{b}$ & $1.09 \pm 0.90^{\mathrm{a}}$ \\
\hline \multirow{5}{*}{ Ovaries } & $7+$ & 5 & $75.63 \pm 0.61^{\mathrm{a}}$ & $24.37 \pm 0.61^{\mathrm{a}}$ & $8.63 \pm 2.46^{\mathrm{a}}$ & $12.45 \pm 1.45^{\mathrm{a}}$ & $1.12 \pm 0.26^{\mathrm{a}}$ & $2.18 \pm 0.99^{\mathrm{ab}}$ \\
\hline & $8+$ & 8 & $74.36 \pm 1.96^{\mathrm{a}}$ & $25.64 \pm 1.96^{\mathrm{a}}$ & $7.04 \pm 1.85^{\mathrm{a}}$ & $12.51 \pm 1.10^{\mathrm{a}}$ & $0.64 \pm 0.23^{\mathrm{a}}$ & $5.45 \pm 1.32^{\mathrm{a}}$ \\
\hline & $9+$ & 5 & $80.61 \pm 2.61^{\mathrm{a}}$ & $19.39 \pm 2.61^{\mathrm{a}}$ & $3.56 \pm 0.73^{\mathrm{a}}$ & $13.35 \pm 1.76^{\mathrm{a}}$ & $0.78 \pm 0.23^{\mathrm{a}}$ & $1.69 \pm 0.54^{\mathrm{b}}$ \\
\hline & $10+$ & 6 & $75.87 \pm 0.86^{\mathrm{a}}$ & $24.13 \pm 0.86^{\mathrm{a}}$ & $4.35 \pm 0.76^{\mathrm{a}}$ & $15.98 \pm 1.15^{\mathrm{a}}$ & $0.95 \pm 0.16^{\mathrm{a}}$ & $2.85 \pm 0.41^{\mathrm{ab}}$ \\
\hline & $11+$ & 3 & $76.49 \pm 1.32^{\mathrm{a}}$ & $23.51 \pm 1.32^{\mathrm{a}}$ & $2.82 \pm 0.09^{\mathrm{a}}$ & $16.69 \pm 0.42^{\mathrm{a}}$ & $1.06 \pm 0.11^{\mathrm{a}}$ & $2.94 \pm 1.13^{\mathrm{ab}}$ \\
\hline
\end{tabular}

Note: different letters in the column indicate values that significantly differ one from another between individuals of different age separately for the muscular tissue, liver, testes and ovaries taking into account Bonferroni correction $(\mathrm{P}<0.05)$.

In the liver of bream of the Uglich Reservoir, water content increased till the age $7+$, and then fell to a minimum and at age of $9+$ increased again. After decrease in the fat content in the liver of bream aged $6+$ to $8+$, we observed an almost two-fold increase in this parameter at the age of 9+. Protein content changed inversely proportionate to the water. Ash content increased up to maximum at the age of $9+$, and then decreased and increased again. In the liver of bream, there occurred alternation of decrease and increase in carbohydrates with age (Table 8).

In the gonads of bream of the Uglich Reservoir, in the period between eight and nine years, the content of water, protein and mineral substances significantly increased, while that of fat significantly decreased (Table 8).

In the ovaries, we saw alternation of decrease and growth of water content. The level of fat during the general decreasing trend with age $8+$ changed inversely proportionate to the water content, while that of protein increased. In the period between the ages $7+$ to $8+$, we determined a 2 -fold decrease in ash with following increase till the age of 11+. Age-related changes of the content of carbohydrates in the gonads of female bream were expressed poorly (Table 8).

After increase in the water content in the muscles of bream of the Ivankovo Reservoir, there occurred alternation of decrease and accumulation in this parameter in the age period from $5+$ to $7+($ Table 9). Level of lipids in the context of general decreasing trend achieved the lowest value at the age of 9+. Protein content decreased till the age of seven years, and from age $8+$ increase and decrease alternated. Ash content changed in parabola form: from maximum at the age of $5+$ it decreased to minimum at the age of $9+$, and then increased till 12+. Assessment of content of carbohydrates in the skeletal muscles of bream in the period from five to twelve years showed alternation between positive and negative shifts in the interval of $1.77-0.09 \%$.

In the liver of bream from the Ivankovo Reservoir, the water level decreased till the age of $7+$, and then the parameter was characterized by increasing trend. Fat content in the liver of bream changed inversely pro- portionate to that of water. With age, there was alternation of positive and negative shifts in the content of protein within $4.32-9.60 \%$ and ash in the interval of $0.40-1.04 \%$, the lowest values of the both parameters were seen in 12-year old individuals. The amount of carbohydrates increased until the age of $7+$, and then the parameter was characterized by decreasing trend, reaching minimum at the age of $12+$ (Table 9).

In the testes of bream from the Ivankovo Reservoir, in the period between $8+$ to $10+$ years, there occurred alternation of decrease and increase in water content and mineral substances. Content of fat and carbohydrates increased till the age of $9+$, and then decreased at $10+$, protein - decreased with age (Table 9).

In the ovaries of bream from the Ivankovo Reservoir, we observed inverse relationship between age-related changes in the contents of water and fat. Content of protein tended to increase with age, peaking at 12+. Content of ash and carbohydrates increased with age equally, being within $0.64-1.80 \%$ for mineral substances and $0.68-3.92 \%$ for carbohydrates (Table 9).

\section{Discussion}

Indices of the physiological condition of fish may reflect the health and wellbeing of individuals and be criteria for evaluating the living conditions of hydrobionts (Teubner et al., 2015; Arame et al., 2020; Khillare \& Khandare, 2020; Tenji et al., 2020). The indices of physical conditions are considered to positively correlate with the content of lipids in the organism of fish (Salam \& Davies, 1994; McPherson et al., 2011; Pradhan et al., 2015; Ahmed \& Sheikh, 2017). In bream, Fulton's indices of physiological condition may vary within 1.17-3.55 (Kangur, 1996; Tierney et al., 1999; Khristenko \& Kotovska, 2017; Flerova et al., 2019a, 2019b, 2020), and Clark's indices-1.25-3.29 (Chuiko et al., 2007; Lapirova et al., 2017; Flerova et al., 2019a, 2019b, 2020; Payuta et al., 2019; Yurchenko \& Morozov, 2019). 
As known, the content of biochemical components in the body of hydrobionts is subject to first of all their living and feeding conditions (Reinitz et al., 1979; Berge et al., 2009; Lund et al., 2011; Payuta et al., 2018; 2019a). The area of the water surface of the Ivankovo and Uglich Reservoirs is significantly smaller than that of the Gorky Reservoir, and therefore the level of influence of various factors in the water bodies varies. Accordingly, scientific assessment of the degree of thermal pollution revealed that heated waters affect the ecosystem of the Ivankovo Reservoir in the $3 \mathrm{~km}$ stretch in the zone of high heating and 15 to $25 \mathrm{~km}$ in the zone of weak heating depending on the season. In the Gorky Reservoir, the influence of heightened temperatures was localized within $17 \mathrm{~km}$ in summer and $30 \mathrm{~km}$ in winter (Kopylov, 2001; Perova et al., 2018; Verbitsky et al., 2018).

In summer, in the area of drainage of warm waters into the Moshkovskiy bay of the Ivankovo Reservoir, high water temperatures that were measured that exceeded the norm, which in turn leads to negative impact on the development of macrozoobenthos (Kopylov, 2001; Lazareva et al., 2018a; 2018b). The Uglich and Ivankovo Reservoirs were characterized by high productivity of the benthic communities, but the oxygen deficiency found in the survey period in the near-bottom layer of these water bodies led to decrease in the species diversity and population of benthic animals, while the overall biomass of macrozoobenthos in the Gorky Reservoir increased (Zhiteneva, 1998; Lazareva et al., 2018b; Perova et al., 2018). Furthermore, increase in water temperature affects the physiological condition of bream by reducing solubility of oxygen and causing critical values of the parameter, the fish being observed to have feeding inhibition (Buentello et al., 2000; Shoji et al., 2005; Tran-Duy et al., 2008; Araújo-Luna et al., 2018). Heightened water temperatures of water together with various toxicants may take negative impact on the condition of hydrobionts (Adams, 1999; Golovanov, 2013; Lazareva et al., 2018b). Perahaps those were the reasons why the bream of the Gorky Reservoir had higher content of dry matter, including protein and mineral substances in the muscles and the liver than the bream of the Uglich and Ivankovo reservoirs.

Table 9

Biochemical parameters of muscles, liver and gonads of bream of different ages from the Ivankovo Reservoir $(\mathrm{x} \pm \mathrm{SE})$

\begin{tabular}{|c|c|c|c|c|c|c|c|c|}
\hline \multirow{2}{*}{ Organ / tissue } & \multirow{2}{*}{ Age } & \multirow{2}{*}{$\mathrm{n}$} & \multicolumn{6}{|c|}{ Content, $\%$} \\
\hline & & & water & dry matter & lipids & protein & ash & carbohydrates \\
\hline \multirow{8}{*}{ Muscle } & $5+$ & 4 & $79.03 \pm 0.22^{\mathrm{a}}$ & $20.97 \pm 0.22^{\mathrm{a}}$ & $1.35 \pm 0.23^{\mathrm{a}}$ & $18.03 \pm 0.05^{\mathrm{a}}$ & $1.50 \pm 0.16^{\mathrm{a}}$ & $0.09 \pm 0.01^{\mathrm{a}}$ \\
\hline & $6+$ & 6 & $80.87 \pm 0.79^{\mathrm{a}}$ & $19.13 \pm 0.79^{\mathrm{a}}$ & $1.32 \pm 0.24^{\mathrm{a}}$ & $15.39 \pm 0.90^{\mathrm{a}}$ & $1.31 \pm 0.15^{\mathrm{ab}}$ & $1.11 \pm 0.52^{\mathrm{ab}}$ \\
\hline & $7+$ & 6 & $81.73 \pm 0.41^{\mathrm{a}}$ & $18.27 \pm 0.41^{\mathrm{a}}$ & $1.16 \pm 0.05^{\mathrm{a}}$ & $15.11 \pm 0.31^{\mathrm{a}}$ & $1.07 \pm 0.06^{\mathrm{ab}}$ & $0.93 \pm 0.21^{\mathrm{ab}}$ \\
\hline & $8+$ & 5 & $80.89 \pm 0.27^{\mathrm{a}}$ & $19.11 \pm 0.27^{\mathrm{a}}$ & $1.01 \pm 0.10^{\mathrm{a}}$ & $16.26 \pm 0.52^{\mathrm{a}}$ & $1.00 \pm 0.05^{\mathrm{b}}$ & $0.83 \pm 0.32^{\mathrm{ab}}$ \\
\hline & $9+$ & 7 & $81.20 \pm 0.55^{\mathrm{a}}$ & $18.80 \pm 0.55^{\mathrm{a}}$ & $0.79 \pm 0.06^{\mathrm{a}}$ & $15.30 \pm 0.77^{\mathrm{a}}$ & $0.94 \pm 0.04^{\mathrm{b}}$ & $1.77 \pm 0.45^{\mathrm{b}}$ \\
\hline & $10+$ & 6 & $80.84 \pm 0.25^{\mathrm{a}}$ & $19.16 \pm 0.25^{\mathrm{a}}$ & $1.08 \pm 0.27^{\mathrm{a}}$ & $15.94 \pm 0.14^{\mathrm{a}}$ & $1.02 \pm 0.04^{\mathrm{b}}$ & $1.13 \pm 0.19^{\mathrm{ab}}$ \\
\hline & $11+$ & 5 & $81.14 \pm 1.25^{\mathrm{a}}$ & $18.86 \pm 1.25^{\mathrm{a}}$ & $0.74 \pm 0.33^{\mathrm{a}}$ & $15.78 \pm 0.98^{\mathrm{a}}$ & $1.04 \pm 0.20^{\mathrm{ab}}$ & $1.30 \pm 0.26^{\mathrm{ab}}$ \\
\hline & $12+$ & 4 & $81.23 \pm 0.39^{\mathrm{a}}$ & $18.77 \pm 0.39^{\mathrm{a}}$ & $0.92 \pm 0.32^{\mathrm{a}}$ & $16.11 \pm 0.28^{\mathrm{a}}$ & $1.10 \pm 0.03^{\mathrm{ab}}$ & $0.65 \pm 0.25^{\mathrm{ab}}$ \\
\hline \multirow{9}{*}{ Liver } & $4+$ & 11 & $86.53 \pm 0.11^{\mathrm{ac}}$ & $13.47 \pm 0.11^{\mathrm{ac}}$ & $2.44 \pm 0.12^{\mathrm{a}}$ & $7.35 \pm 0.13^{\mathrm{ab}}$ & $0.75 \pm 0.16^{\mathrm{abc}}$ & $2.94 \pm 0.03^{\mathrm{abc}}$ \\
\hline & $5+$ & 5 & $85.18 \pm 0.08^{\mathrm{abc}}$ & $14.82 \pm 0.08^{\mathrm{abc}}$ & $3.15 \pm 0.08^{\mathrm{a}}$ & $8.03 \pm 0.04^{\mathrm{a}}$ & $1.04 \pm 0.03^{\mathrm{a}}$ & $2.61 \pm 0.02^{\mathrm{abc}}$ \\
\hline & $6+$ & 6 & $81.28 \pm 0.04^{\mathrm{ab}}$ & $18.72 \pm 0.04^{\mathrm{ab}}$ & $5.73 \pm 0.02^{\mathrm{a}}$ & $9.60 \pm 0.22^{\mathrm{a}}$ & $0.98 \pm 0.08^{\mathrm{ab}}$ & $2.42 \pm 0.20^{\mathrm{abc}}$ \\
\hline & $7+$ & 9 & $79.84 \pm 2.44^{\mathrm{b}}$ & $20.16 \pm 2.44^{b}$ & $6.31 \pm 1.48^{\mathrm{a}}$ & $9.17 \pm 0.79^{\mathrm{a}}$ & $0.76 \pm 0.08^{\mathrm{ab}}$ & $3.93 \pm 0.38^{\mathrm{a}}$ \\
\hline & $8+$ & 20 & $82.37 \pm 0.57^{\mathrm{ab}}$ & $17.63 \pm 0.57^{\mathrm{ab}}$ & $5.27 \pm 0.44^{\mathrm{a}}$ & $8.39 \pm 0.53^{\mathrm{a}}$ & $0.68 \pm 0.03^{\mathrm{bc}}$ & $3.29 \pm 0.26^{\mathrm{ac}}$ \\
\hline & $9+$ & 12 & $83.20 \pm 0.29^{\mathrm{ab}}$ & $16.80 \pm 0.29^{\mathrm{ab}}$ & $4.78 \pm 0.37^{\mathrm{a}}$ & $7.67 \pm 0.30^{\mathrm{a}}$ & $0.69 \pm 0.07^{\mathrm{bc}}$ & $3.66 \pm 0.27^{\mathrm{ac}}$ \\
\hline & $10+$ & 9 & $81.91 \pm 1.03^{\mathrm{ab}}$ & $18.09 \pm 1.03^{\mathrm{ab}}$ & $5.98 \pm 0.91^{\mathrm{a}}$ & $7.84 \pm 0.31^{\mathrm{a}}$ & $0.72 \pm 0.05^{\mathrm{ab}}$ & $3.55 \pm 0.18^{\mathrm{ac}}$ \\
\hline & $11+$ & 4 & $84.27 \pm 0.95^{\mathrm{ab}}$ & $15.73 \pm 0.95^{\mathrm{ab}}$ & $4.72 \pm 0.89^{\mathrm{a}}$ & $7.69 \pm 0.13^{\mathrm{a}}$ & $0.85 \pm 0.04^{\mathrm{ab}}$ & $2.47 \pm 0.19^{b c}$ \\
\hline & $12+$ & 3 & $91.64 \pm 0.00^{c}$ & $17.71 \pm 0.00^{\mathrm{c}}$ & $2.56 \pm 0.04^{\mathrm{a}}$ & $4.32 \pm 0.18^{\mathrm{b}}$ & $0.40 \pm 0.02^{\mathrm{c}}$ & $1.09 \pm 0.24^{\mathrm{b}}$ \\
\hline \multirow{3}{*}{ Testes } & $8+$ & 10 & $70.84 \pm 6.75^{\mathrm{a}}$ & $29.16 \pm 6.75^{\mathrm{a}}$ & $17.42 \pm 5.98^{\mathrm{a}}$ & $8.92 \pm 0.39^{\mathrm{a}}$ & $1.09 \pm 0.08^{\mathrm{a}}$ & $1.73 \pm 1.27^{\mathrm{a}}$ \\
\hline & $9+$ & 3 & $61.22 \pm 6.41^{\mathrm{a}}$ & $38.78 \pm 6.41^{\mathrm{a}}$ & $26.14 \pm 5.49^{a}$ & $7.27 \pm 1.29^{\mathrm{a}}$ & $0.84 \pm 0.11^{\mathrm{a}}$ & $4.54 \pm 2.58^{\mathrm{a}}$ \\
\hline & $10+$ & 3 & $67.54 \pm 0.05^{\mathrm{a}}$ & $32.46 \pm 0.05^{\mathrm{a}}$ & $23.70 \pm 0.30^{\mathrm{a}}$ & $6.63 \pm 0.18^{\mathrm{a}}$ & $0.90 \pm 0.16^{\mathrm{a}}$ & $1.24 \pm 0.69^{\mathrm{a}}$ \\
\hline \multirow{9}{*}{ Ovaries } & $4+$ & 8 & $64.64 \pm 0.14^{\mathrm{a}}$ & $29.16 \pm 0.14^{\mathrm{a}}$ & $19.90 \pm 1.65^{\mathrm{a}}$ & $10.53 \pm 0.40^{\mathrm{a}}$ & $1.48 \pm 0.22^{\mathrm{a}}$ & $3.46 \pm 0.89^{\mathrm{a}}$ \\
\hline & $5+$ & 4 & $72.78 \pm 0.01^{\mathrm{a}}$ & $27.22 \pm 0.01^{\mathrm{a}}$ & $13.48 \pm 0.18^{\mathrm{a}}$ & $10.94 \pm 0.08^{\mathrm{a}}$ & $1.39 \pm 0.69^{\mathrm{a}}$ & $1.41 \pm 0.95^{\mathrm{a}}$ \\
\hline & $6+$ & 3 & $69.55 \pm 0.00^{\mathrm{a}}$ & $30.45 \pm 0.00^{\mathrm{a}}$ & $18.37 \pm 0.73^{\mathrm{a}}$ & $10.00 \pm 0.62^{\mathrm{a}}$ & $1.07 \pm 0.07^{\mathrm{a}}$ & $1.01 \pm 0.18^{\mathrm{a}}$ \\
\hline & $7+$ & 6 & $80.13 \pm 1.47^{\mathrm{a}}$ & $19.87 \pm 1.47^{\mathrm{a}}$ & $5.99 \pm 1.51^{\mathrm{a}}$ & $10.60 \pm 0.65^{\mathrm{a}}$ & $1.40 \pm 0.12^{\mathrm{a}}$ & $1.89 \pm 0.54^{\mathrm{a}}$ \\
\hline & $8+$ & 10 & $72.58 \pm 1.33^{\mathrm{a}}$ & $27.42 \pm 1.33^{\mathrm{a}}$ & $11.21 \pm 1.93^{\mathrm{a}}$ & $11.16 \pm 0.80^{\mathrm{a}}$ & $1.13 \pm 0.20^{\mathrm{a}}$ & $3.92 \pm 1.37^{\mathrm{a}}$ \\
\hline & $9+$ & 9 & $74.61 \pm 2.18^{\mathrm{a}}$ & $25.39 \pm 2.18^{\mathrm{a}}$ & $10.23 \pm 3.17^{\mathrm{a}}$ & $12.68 \pm 0.71^{\mathrm{a}}$ & $1.80 \pm 0.37^{\mathrm{a}}$ & $0.68 \pm 0.46^{\mathrm{a}}$ \\
\hline & $10+$ & 6 & $73.27 \pm 2.92^{\mathrm{a}}$ & $26.73 \pm 2.92^{\mathrm{a}}$ & $11.48 \pm 3.85^{\mathrm{a}}$ & $12.74 \pm 0.86^{\mathrm{a}}$ & $0.89 \pm 0.17^{\mathrm{a}}$ & $1.63 \pm 0.82^{\mathrm{a}}$ \\
\hline & $11+$ & 4 & $80.53 \pm 2.23^{\mathrm{a}}$ & $19.47 \pm 2.23^{\mathrm{a}}$ & $6.37 \pm 0.41^{\mathrm{a}}$ & $11.38 \pm 2.04^{\mathrm{a}}$ & $0.64 \pm 0.29^{\mathrm{a}}$ & $1.08 \pm 0.91^{\mathrm{a}}$ \\
\hline & $12+$ & 3 & $64.60 \pm 8.62^{\mathrm{a}}$ & $35.40 \pm 8.62^{\mathrm{a}}$ & $14.62 \pm 5.76^{\mathrm{a}}$ & $16.69 \pm 3.23^{\mathrm{a}}$ & $1.41 \pm 0.23^{\mathrm{a}}$ & $2.68 \pm 0.97^{\mathrm{a}}$ \\
\hline
\end{tabular}

Note: different letters in the column indicate values that significantly differ one from another between individuals of different age separately for the muscular tissue, liver, testes and ovaries taking into account Bonferroni correction $(\mathrm{P}<0.05)$.

The fish subjected to prolonged influence of heightened temperatures were observed to have increased development of fat, especially tryglicerids, compared with proteins, which may be related to reduced rates of metabolic processes with lipids during thermal acclimatization (Lukyanenko et al., 1983; Smirnov \& Bogdan, 1997; Tidwell et al., 2003). The fact that the samples for the research were taken in summer in the Uglich and Ivankovo resrvoirs and in autumn in the Gorky Reservoir may explain the lower accumulation of fat in the muscular tissues and the liver of bream of the Gorky Reservoir compared with the bream populations of the Uglich and Ivankovo reservoirs.

We should note that, having similar productivity and feeding conditions in the Uglich and Ivankovo Reservoirs (Mineeva \& Makarova, 2018; Perova et al., 2018; Mineeva, 2019), the bream had similar parameters of metabolism in the muscles, while having significant differences in the liver. In the water and benthic sediments in the Uglich Reservoir, we observed heightened concentrations of pollutants compared with the Ivankovo Reservoir (Gapeeva \& Zakonnov, 2016; Tolkachev et al., 2017; Tolkachev, 2019). Hepatic lipids that perform a protective role concentrate pollutants, thereby preventing their ingress to other organs (Adams, 1999; Ribeiro et al., 2005; Sun et al., 2018). Perhaps, the high content of fat in the liver of bream of the Uglich Reservoir, compared with the liver of bream of other studied water bodies, may be related to a complex of thermal influence and impact caused by the pollutants (Lal \& Singh, 1987; German \& Kozlovskaya, 2001; Kruchkov et al., 2006).

Low values of protein and ash in the muscles of bream of the Uglich Reservoir may be explained by unfavourable environmental conditions due to anthropogenic impact on the water body (Gapeeva \& Zakonnov, 2016; Lazareva, 2016; Tolkachev et al., 2017). The lower content of lipids in the gonads of bream of the Uglich and Ivankovo Reservoirs, compared with those of the Gorky Reservoir, is likely related to the energy expenditure mechanisms of synthesis of protein products in the gonads and their recovery in unfavourable living conditions. Thus, intensity of accumulation of metabolic products in the muscles, liver and gonads of bream of various water bodies is likely different because of the overall effect of the abovementioned peculiarities of each water body. Comparison of the parameters of metabolism in the muscular tissues of bream groups of 
different sexes from different water bodies revealed that their contents were similar. Nevertheless, the male bream in the studied water bodies were observed to have less protein and more carbohydrates in the muscular tissues compared with females and immature individuals. Skeletal muscles of female bream were characterized by decreased content of water and increased amount of dry matter compared with male and immature bream. In the muscles of juvenile specimens, there was seen low content of fat compared with mature bream (Table 3, 5, 6). Earlier, research revealed that in bodies of fish, regardless of their living location, the amount of metabolic products differed insignificantly (Nargis, 2006; Yousaf et al., 2011; Payuta et al., 2019a; Payuta \& Flerova, 2019). Reduced content of protein and increased amount of carbohydrates in the muscles of males were determined in marine and freshwater fish, including Cyprinidae, in a number of studies (Medford \& Mackay, 1978; Nargis, 2006; Payuta et al., 2019a). The studies of chemical composition in the bodies of Cyprinidae and Pleuronectidae found higher content of fat in the bodies of mature fish compared with immature specimens (Rijnsdorp \& Ibelings, 1989; Payuta et al., 2019a; Payuta \& Flerova, 2019). If the mature fish were characterized by dominance of fat accumulation over protein synthesis, the juvenile stage was characterized by inverse dynamics. Similar dynamics in young individuals is related to more intense energy metabolism because of their greater mobility and energy expenditures for somatic growth till sexual maturity in order to be able to avoid predators and effectively find food and develop the reproductive system (Dutta, 1994; Shulman \& Love, 1999; Lloret et al., 2014).

A difference was determined in the content of metabolic products in the liver between males and female bream, but the orientation of these differences varied in different water bodies. In females from the studied water bodies, the content of mineral substances in the liver alone was greater compared with the males. We determined sex-related correlation between changes in the amount of protein in the liver for bream of the Gorky and Uglich reservoirs, and dry matter and carbohydrates for breams of the Uglich and Ivankovo Reservoirs (Tabls 3, 5, 6). The concentration of metabolic products in the liver of bream is likely to be more influenced by the environmental conditions rather than sex. For example, in the liver of Atlantic cod Gadus morhua living in different water bodies, high content of fat and carbohydrates was found both in males and females (Krivobok \& Tarkovskaya, 1964; Jangaard et al., 1967; Addison et al., 1968; Bogoyavlenskaya \& Veltishcheva, 1972; Dey et al., 1983).

Sexual diamorphism of biochemical composition in the gonads was expressed more strongly: content of fat in the testes was higher, while the amount of protein was significantly lower than in the ovaries (Table 3, 5, 6). During the transition of the gonads from stage II of maturity to stage III, a decrease was seen in the content of dry matter, including fat, in the sex glands of bream from the examined water bodies (Table 4). With increase in stage of maturity of the gonads, we observed similar changes in the amount of mineral substances in the sex glands of bream of the Gorky and Uglich Reservoirs, carbohydrates - in bream of the Gorky and Ivankovo Reservoirs. As known, the metabolic processes in the testes and ovaries significant dependend on stage of sexual cycle. Content of metabolic products in the sex glands changed at certain stages of the gonads' maturity regardless of a species' environment (Hendry \& Berg, 1999; Zaboukas et al., 2006; Nogueira et al., 2017; Payuta \& Flerova, 2019). For example, the studies of sockeye salmon Oncorhynchus nerka of the water bodies of Russia, USA and Canada revealed that the gonads of females collected in the period of spawning migration had greater content of dry matter and fat than the sex glands of males (Idler \& Bitners, 1960; Hendry \& Berg, 1999; Shershneva \& Gorodovskaya, 2010). A number of studies revealed that the ovaries of fish, including Cyprinidae, contain higher amount of protein compared with the testes, which correlates with the results of our study (Domashenko et al., 1975; Hanna, 1984; Payuta \& Flerova, 2019).

During the transition of the gonads of the examined bream from maturity stage II to stage III, they were observed to have similar changes in the contents of dry matter and lipids. It is considered that during vitellogenesis and the yolk stage the sexual glands mainly synthesize essential aminoacids, and structural lipids are being developed from free fatty acids. Most proteins and lipids that are introduced to the gonads come from food (Shulman \& Love, 1999; Lloret et al., 2014; Maslova, 2019). This is possibly why the dynamics of accumulation of metabolic products in the sex glands of bream living in different conditions during development of the gonads vary. Our presumptions are confirmed by the studies of biochemical composition of the gonads of Atlantic herring Chpea harengus of various water bodies. During maturation of male bream in the water bodies of USA, the content of fat in the testes decreased, in Scotalnd and the Sea of Okhotsk - increased (Bruce, 1924; Henderson \& Almatar, 1989; Gorbatenko et al., 2018).

As a result of the studies, the environmental factors were found to have a stronger effect on the contents of metabolic products in the muscles and the organs of bream than age. In the liver alone, the bream from the examined water bodies were found to have some patterns: the greatest amount of biochemical components in the organ was concentrated in individuals aged 6 to 10 (Tables 7-9).

Despite the uneven dynamics of the content of lipids and carbohydrates in the gonads of bream with age, the testes and ovaries of the individuals were observed to have increase in the parameters till a certain age with subsequent decrease in older groups (Table 7-9).

In the muscular tissue of bream from the Ivankovo Reservoir, we observed a tendency towards increase in water content with age, whereas individuals of the Gorky Reservoir had no such a dependency (Table 7-9). The studies of chemical composition of marine and freshwater fish report both increase and decrease in the water content in the muscles with age (Borisov \& Shatunovskii, 1973; Naeem \& Ishtiaq, 2011; Payuta et al., 2019a; Payuta \& Flerova, 2019). High water content in the muscles may be related to the expenditures of muscular protein and lipids during both hunger and spawning, for it replaces these components when the organism spends the energy it increasingly needs due to increases in the relative weight of spawning products (Borisov \& Shatunovskii, 1973; Dawson \& Grimm, 1980; Flath \& Diana, 1985; Ali et al., 2005). Such changes in the metabolic processes in the organisms of fish indicate exhaustion of individuals, deterioration of their wellbeing due to which the probability of their death increases under the influence of biotic and abiotic factors (Borisov \& Shatunovskii, 1973; Martemyanov, 2013, 2015). Decrease with age in the amount of water in the muscles of bream of the Gorky and Uglich Reservoirs may indicate more favourable living conditions compared with the Ivankovo Reservoir.

Dynamics in the parameters of lipid, protein and mineral metabolisms in the muscles of bream of the Gorky and Uglich Reservoirs had an overall correlational relationship (Table 7-9). In the skeletal muscles of older groups of bream $(10+, 11+)$ of these reservoirs, there were found the highest contents of fat, protein and mineral substances, whereas in the Ivankovo Reservoir, the highest values of these parameters were seen for fiveyear old individuals (Tables 7-9). The favourable conditions in the zone of influence of heated waters in the Ivankovo Reservoir promoted concentration of young individuals of heat-loving species, including bream (Hölker, 2006; Golovanov \& Smirnov, 2011; Golovanov, 2013). This is likely associated with the accumulation of fat and protein reserves in the muscles of five-year old bream in the Ivankovo Reservoir, whereas those in the Gorky and Uglich Reservoirs had the highest amounts of these components in the muscles of ten- and eleven-years old individuals. The relatively low contents of lipids and protein in bream aged 2+ to 4+ are likely related to difficult feeding conditions in the sublitoral zone. The rich biocoenosis of phytophile larvae of Chironomidae and Cladocera is inaccessible to the young individuals due to body structure in that period of the development, but with increase in size, the individuals become better at finding food in the benthic sediments, including deep layers (Zhiteneva et al., 1984; Lammens \& Hoogenboezem, 1991; Zhiteneva, 1998; Persson \& Brönmark, 2002).

Thus, we may presume that the living conditions (temperature, oxygen concentration, pollutants, feeding conditions, etc.) have a stronger effect in the content of metabolic products in the muscles than age. Similarly, a number of authors found different dynamics of accumulation of protein with age in the body of pike Esox lucius living in different water bodies (Medford \& Mackay, 1978; Salam \& Davies, 1994; Hadjinikolova \& Zaikov, 2006).

The literature does not report similar dynamics in the accumulation of metabolic products in the liver of individuals of a species which live in different conditions. In the liver of Atlantic cod of the Baltic Sea, the 
amount of fat changed equally with age, having a the tendency towards decrease, whereas in the Bering Sea it increased; a similar tendency to agerelated changes in glycogen was found in the liver of Capoeta umbla from the lakes of Turkey with different living conditions (Krivobok \& Tarkovskaya, 1964; Bogoyavlenskaya \& Veltishcheva, 1972; Coban \& Sen, 2011). Perhaps, similar changes occurring in the liver of bream of the Upper Volga Reservoirs, specifically the accumulation of metabolic products in middleaged individuals is a peculiarity of the ecology of this species.

The gonads of the female and male bream we examined were found to have similar dynamics in the contents of fat and carbohydrates with age. The data on content of protein in the testes and ovaries allows us to state inequality between the sexual glands of breams of different age. Nonetheless, compared with the fat content, the amount of protein was characterized by higher stability. It is interesting to note the higher content of protein in the ovaries of bream aged 10+ and 11+ of the Uglich and Ivankovo Reservoirs compared with the gonads of female bream of other ages. A number of studies discovered increase in protein concentration in the ovaries with increase in size and age of the marine fish (Grauman, 1972; Domashenko et al., 1975; Veltishcheva \& Tokareva, 1978; Boyko \& Ruzhinskaya, 2019). In the testes and ovaries of bream, there was found a tendency to accumulation of lipids, which corresponds to accumulation of dry content and is inversely proportionate to water content. It is likely related to the fact that dry matter in the sex glands of fish is to a larger degree represented by fat. Inverse correlation between the contents of lipids and water in the organism of fish, including their sex glands, is shown in many studies (Jafri, 1969; Craig, 1977; Grigorakis \& Alexis, 2005; Zaboukas et al., 2006; Bilokon et al., 2013; Rudenko et al., 2019; Payuta \& Flerova, 2019).

\section{Conclusions}

Thus, biochemical parameters of the muscles, the liver and gonads of bream living in different reservoirs of the Upper Volga to a greater degree depend on the complex impact of factors of the aquatic environment which are characteristic of each water body, rather than sex, stage of maturity of the gonads and age of specimens. Higher contents of protein and mineral substances in the muscles and liver of bream of the Gorky Reservoir were associated with more favourable living conditions in it compared with the Uglich and Ivankovo Reservoirs, in which we observed increased water temperature and low oxygen concentration that reduces the species diversity and populations of benthic animals, as well as negatively affecting the appetite of fish. Higher content of lipids in the liver of bream of the Uglich Reservoir may be due to high overall water temperature and presence of pollutants in it and benthic deposits, for lipids concentrate the pollutants, thus preventing their distribution in the organism. For juvenile bream of the Upper Volga prevalence of protein synthesis over the accumulation of lipids was characteristic because of their need for energy for somatic growth in order to be able to avoid predators and effectively find food and develop the reproductive system. Inequal dynamics of biochemical parameters in the gonads of bream during their maturation is due to different feeding conditions of the reservoirs, because most proteins and lipids that are introduced to the gonads in phases II and III come from food. In the Ivankovo Reservoir, heated waters have a positive effect on the young bream as a result of increasing the period of fattening and better development of a food base, as indicated by the higher content of biochemical components in specimens aged 5+ compared with individuals of older groups and bream of the examined water bodies. In the organism of bream, a inverse dependency was seen between the fat and water amounts, indicating the fact that lipids in different tissues and organs have a notable hydrophoby that affects the content of the metabolic products. We may pressume that increase in the parameters of metabolism demonstrates that the energy from them was spent on supporting the systems and the organs in order to alleviate the unfavourable living conditions of this species. The data we obtained allow assessment of the physiological condition of bream for rational organization of fishing and management of fish populations.

Financial support: Russian Ministry of Science and Higher Education, Project No. 0856-2020-0008.
The authors would like to thank the staff of the Laboratory of Ecology of Fish of the Papanin Institute for Biology of Inland Waters Russian Academy of Sciences for help in collecting the material and indentifying the age of the fish. Also, we would wish to thank Y. V. Gerasimov, D. P. Karabanov, M. I. Bazarov, D. D. Pavlov, M. I. Malin and A. A. Bolotovsky (IBIW RAS) for their help in analysis of the material.

The authors claim no conflict of interests.

\section{References}

Adams, S. M. (1999). Ecological role of lipids in the health and success of fish populations. In: Arts, M. T., \& Wainman, B. C. (Eds.). Lipids in freshwater ecosystems. Springer. Pp. 132-160.

Addison, R. F., Ackman, R. G., \& Hingley, J. (1968). Distribution of fatty acids in cod flesh lipids. Joumal of the Fisheries Board of Canada, 25(10), 2083-2090.

Ahmed, I., \& Sheikh, Z. A. (2017). Study on the seasonal variation in the chemical composition, hematological profile, gonado-somatic index and hepato-somatic index of snow trout, Schizothorax niger from the freshwater Dal Lake, Kashmir. American Journal of Food Technology, 12(1), 1-13.

Ali, M., Iqbal, F., Salam, A., Iram, S., \& Athar, M. (2005). Comparative study of body composition of different fish species from brackish water pond. International Journal of Environmental Science and Technology, 2(3), 229-232.

Amara, R., Meziane, T., Gilliers, C., Hermel, G., \& Laffargue, P. (2007). Growth and condition indices in juvenile sole Solea solea measured to assess the quality of essential fish habitat. Marine Ecology Progress Series, 351, 201-208.

Arame, H., Adite, A., Adjibade, N. K., Imorou, R. S., \& Sonon, P. P. (2020). Lengthweight relationships and condition factors of Mochokidae (Pisces: Teleostei: Siluriformes) from Niger River, Northern Benin. Aquatic Research, 3(2), 72-84.

Araújo-Luna, R., Ribeiro, L., Bergheim, A., \& Pousão-Ferreira, P. (2018). The impact of different rearing condition on gilthead seabream welfare: Dissolved oxygen levels and stocking densities. Aquaculture Research, 49(12), 3845-3855.

Bano, Y. (1977). Seasonal variations in the biochemical composition of Clarias batrachus L. Proceedings of the Indian Academy of Sciences - Section B, 85(3), 147-155.

Berge, G. M., Witten, P. E., Baeverfjord, G., Vegusdal, A., Wadsworth, S., \& Ruyter, B. (2009). Diets with different $n-6 / n-3$ fatty acid ratio in diets for juvenile Atlantic salmon, effects on growth, body composition, bone development and eicosanoid production. Aquaculture, 296, 299-308.

Bilokon, G. S., Marenkov, O. M., \& Dvoretskiy, A. I. (2013). Contents of radionuclides and heavy metals in fish roe of commercial fish of the Zaporizhya Reservoir. Nuclear Physics and Atomic Energy, 14(1), 81-85.

Biro, P. A., Morton, A. E., Post, J. R., \& Parkinson, E. A. (2004). Over-winter lipid depletion and mortality of age-0 rainbow trout (Oncorhynchus mykiss). Canadian Joumal of Fisheries and Aquatic Sciences, 61(8), 1513-1519.

Bogoyavlenskaya, M. P., \& Veltishcheva, I. F. (1972). Nekotorye dannye o vozrastnyh izmeneniyah $\mathrm{v}$ zhirovom i uglevodnom obmene treski Baltijskogo morya [Some data on age-related changes in fat and carbohydrate metabolism of the Baltic Sea cod]. VNIRO Proceedings, 85, 56-62 (in Russian).

Borisov, V. M., \& Shatunovskii, M. I. (1973). O vozmozhnosti primeneniya pokazatelya ovodnennosti tkanej dlya ocenki estestvennoj smertnosti barencevomorskoj treski [On the possibility of using the tissue water content indicator to assess the natural mortality of the Barents Sea cod]. VNIRO Proceedings, 93, 311-321 (in Russian).

Boyko, N. E., \& Ruzhinskaya L. P. (2019). Harakteristika funkcionalnogo sostoyaniya chemomorskogo kalkana Scophthalmus maeoticus maeoticus v razlichnye periody reproduktivnogo cikla po materialam issledovanij 2009-2017 gg [Characterization of the functional state of the Black Sea turbot Scophthalmus maeoticus maeoticus at different periods of the reproductive cycle, based on the research data from 2009-2017]. Proceedings of AzNIIRKH, 2, 31-39 (in Russian).

Bruce, J. R. (1924). Changes in the chemical composition of the tissues of the herring in relation to age and maturity. Biochemical Joumal, 18(3-4), 469-485.

Buentello, J. A., Gatlin III, D. M., \& Neill, W. H. (2000). Effects of water temperature and dissolved oxygen on daily feed consumption, feed utilization and growth of channel catfish (Ictalurus punctatus). Aquaculture, 182, 339-352.

Carter, C. G., \& Houlihan, D. F. (2001). Protein synthesis. Fish Physiology, 20, 31-75.

Chang, S. K. C. (2010). Protein analysis. In: Nielsen, S. S. (Ed.). Food analysis. Springer. Pp. 133-146.

Chuiko, G. M., Tillitt, D. E., Zajicek, J. L., Flerov, B. A., Stepanova, V. M., Zhelnin, Y. Y., \& Podgornaya, V. A. (2007). Chemical contamination of the Rybinsk Reservoir, northwest Russia: Relationship between liver polychlorinated biphenyls (PCB) content and health indicators in bream (Abramis brama). Chemosphere, 67(3), 527-536.

Coban, M. Z., \& Sen, D. (2011). Examination of liver and muscle glycogen and blood glucose levels of Capoeta umbla (Heckel, 1843) living in Hazar Lake and Keban Dam Lake (Elazig, Turkey). African Joumal of Biotechnology, 10(50), 10271-10279. 
Collier, T. K., Anulacion, B. F., Arkoosh, M. R., Dietrich, J. P., Incardona, J. P., Johnson, L. L., Ylitalo, G. M., \& Myers, M. S. (2013). Effects on fish of polycyclic aromatic hydrocarbons (PAHs) and naphthenic acid exposures. Fish Physiology, 33, 195-255.

Craig, J. F. (1977). The body composition of adult perch, Perca fluviatilis in Windermere, with reference to seasonal changes and reproduction. The Journal of Animal Ecology, 46(2), 617-632.

Cui, L., Wang, S., Yang, X., Gao, L., Zheng, M., Wang, R., Qiao, L., \& Xu, C. (2018). Fatty acids, polychlorinated dibenzo-p-dioxins and dibenzofurans, and dioxin-like polychlorinated biphenyls in paired muscle and skin from fish from the Bohai coast, China: Benefits and risks associated with fish consumption. Science of the Total Environment, 639, 952-960.

Dabrowski, K., \& Guderley, H. (2003). Intermediary metabolism. In: Halver, J. E., \& Hardy, R. W.(Eds.). Fish nutrition. Third Edition. Academic Press. Pp. 309-365.

Dawson, A. S., \& Grimm, A. S. (1980). Quantitative seasonal changes in the protein, lipid and energy content of the carcass, ovaries and liver of adult female plaice, Pleuronectes platessa L. Joumal of Fish Biology, 16(5), 493-504.

Dey, A. C., Kiceniuk, J. W., Williams, U. P., Khan, R. A., \& Payne, J. F. (1983). Long term exposure of marine fish to crude petroleum - I. Studies on liver lipids and fatty acids in cod (Gadus morhua) and winter flounder (Pseudopleuronectes americanus). Comparative Biochemistry and Physiology Part C: Comparative Pharmacology, 75(1), 93-101.

Domashenko, G. P., Maslennikova, N. V., \& Provotorova, A. N. (1975). Nekotorye osobennosti dinamiki biologicheskih i fiziologicheskih pokazatelej skumbrii v Kel'tskom more [Some features of the dynamics of biological and physiological indicators of mackerel in the Celtic Sea]. VNIRO Proceedings, 96, 101-108. (in Russian).

Dos Santos, J. A., Soares, C. M., \& Bialetzki, A. (2020). Effects of pH on the incubation and early development of fish species with different reproductive strategies. Aquatic Toxicology, 219, 105382.

Dutta, H. (1994). Growth in fishes. Gerontology, 40(2-4), 97-112.

Dzyuban, A. N., Kosolapov, D. B., Korneva, L. G., \& Stolbunova, V. N. (2007). Kompleksnaya ocenka ekologicheskogo sostoyaniya melkovodij Rybinskogo $\mathrm{i}$ Gor'kovskogo vodohranilishch [Complex assessment of the ecological status of the littoral zones in the Rybinsk and Gorkiy Reservoirs]. Inland Water Biology, 4, 3-8 (in Russian).

Elliott, K. H., Roth, J. D., \& Crook, K. (2017). Lipid extraction techniques for stable isotope analysis and ecological assays. In: Bhattacharya, S. (Ed.). Lipidomics. Methods and protocols. Humana Press. Pp. 9-24.

Fang, J., Tian, X., \& Dong, S. (2010). The influence of water temperature and ration on the growth, body composition and energy budget of tongue sole (Cynoglossus semilaevis). Aquaculture, 299, 106-114.

Fawole, O. O., Ogundiran, M. A., Ayandiran, T. A., \& Olagunju, O. F. (2007). Proximate and mineral composition in some selected fresh water fishes in Nigeria. Internet Journal of Food Safety, 9, 52-55.

Filippov, A., Bolotovskiy, A. A., Levin, B. A., \& Golovanova, I. L. (2017). Effect of triiodothyronine on the activity and sensitivity of glycosidases to heavy metals $(\mathrm{Cu}, \mathrm{Zn}$, and $\mathrm{Pb})$ in juvenile blue bream Ballerus ballerus (L.). Inland Water Biology, 10(3), 305-307.

Flath, L. E., \& Diana, J. S. (1985). Seasonal energy dynamics of the alewife in SouthEastern Lake Michigan. Transactions of the American Fisheries Society, 114(3), 328-337.

Flerova, E. A. (2014). Fiziologo-biohimicheskie metody issledovaniya ryb [Physiological and biochemical methods for the study of fish]. Izdatel'stvo Yaroslavl State Agricultural Academy, Yaroslavl (in Russian)

Flerova, E. A., Bogdanova, A. A., Payuta, A. A., Evdokimov, E. G., \& Andreeva, M. I. (2020). Gematologicheskie pokazateli ryb malyh rek gosudarstvennogo prirodnogo zakaznika 'Yaroslavskij" [Hematological indicators of fish of small rivers of the State Nature Reserve "Yaroslavsky"]. VNIRO Proceedings, 179, 78-89 (in Russian)

Flerova, E. A., Malin, M. I., Klyuchnikov, A. S., Payuta, A. A., Bogdanova, A. A., \& Andreeva, M. I. (2019a). Vidovoe raznoobrazie i biologicheskaya harakteristika ryb malyh rek Gosudarstvennogo Prirodnogo Zakaznika "Yaroslavskij”" v postnerestovyj i nagul'nyj periody 2018 goda [Species diversity and biological characteristics of fishes of small rivers of the State Nature Reserve "Yaroslavsky" in the post-birth and fishing periods of 2018]. Transactions of Papanin Institute for Biology of Inland Waters RAS, 87(90), 12-30 (in Russian).

Flerova, E. A., Malin, M. I., Klyuchnikov, A. S., Payuta, A. A., Bogdanova, A. A., \& Andreeva, M. I. (2019b). Vidovoj sostav i biologicheskaya harakteristika ryb malyh rek gosudarstvennogo prirodnogo zakaznika "Yaroslavskij" [Species composition and biological characteristics of small river fishes of the State Nature Reserve "Yaroslavsky"]. Transactions of Papanin Institute for Biology of Inland Waters RAS, 86(89), 80-89 (in Russian).

Ganguly, S., Mahanty, A., Mitra, T., \& Mohanty, B. P. (2017). Proximate composition and micronutrient profile of different size groups of hilsa Tenualosa ilisha (Hamilton, 1822) from river Ganga. Indian Journal of Fisheries, 64, 62-67.

Gapeeva, M. V., \& Zakonnov, V. V. (2016). Geohimicheskaya harakteristika ekosistemy Uglichskogo vodohranilishcha [The geochemical characteristic of the ecosystem of the Uglichsky Reservour]. Transactions of Papanin Institute for Biology of Inland Waters RAS, 75(78), 41-46 (in Russian).

Gerasimov, Y. V., Malin, M. I., Solomatin, Y. I., Bazarov, M. I., \& Brazhnik, S. Y. (2018). Raspredelenie i struktura rybnogo naseleniya $\mathrm{V}$ vodohranilishchah Volzhskogo kaskada v 1980-e i 2010-e gg. [Distribution and structure of fish population in Volga Reservoirs in the 1980s and 2010s]. Transactions of Papanin Institute for Biology of Inland Waters RAS, 82(85), 82-106 (in Russian).

German, A. V., \& Kozlovskaya, V. I. (2001). Gepatosomaticheskij indeks i biohimicheskij sostav pecheni leshcha Abramis brama Sheksninskogo plesa Rybinskogo vodohranilishcha pri razlichnyh urovnyah nakopleniya organicheskih toksikantov [Hepatosomatic index and biochemical composition of the liver of bream Abramis brama in the Sheksna Reach of the Rybinsk Reservoir at different levels of accumulation of organic toxicants]. Voprosy Ihtiologii, 41(2), 249 252 (in Russian).

Golovanov, V. K. (2013). Ecophysiological patterns of distribution and behavior of freshwater fish in thermal gradients. Journal of Ichthyology, 53(4), 252-280.

Golovanov, V. K., \& Smimov, A. K. (2011). Specific features of thermoregulation behavior in early juveniles of roach Rutilus rutilus under thermogradient conditions. Journal of Ichthyology, 51(6), 466-473.

Gorbatenko, K. M., \& Lazhentsev, A. E. (2016). The biochemical composition and calorie density of the walleye pollock Theragra chalcogramma in the Sea of Okhotsk. Russian Journal of Marine Biology, 42(7), 591-601.

Gorbatenko, K. M., Melnikov, I. V., Ovsyannikov, E. E., \& Ovsyannikova, S. L. (2018). Biohimicheskij sostav i kalorijnost' pelagicheskih ryb i kal'marov Ohotskogo morya [Biochemical composition and caloric value of pelagic fish and squids from the Okhotsk sea]. Izvestia TINRO, 195, 74-91 (in Russian)

Grande, M., Murua, H., Zudaire, I., Arsenault-Pemet, E. J., Pernet, F., \& Bodin, N. (2016). Energy allocation strategy of skipjack tuna Katsuwonus pelamis during their reproductive cycle. Journal of Fish Biology, 89(5), 2434-2448.

Grauman, G. B. (1972). Izmenenie biohimicheskogo sostava ikry v zavisimosti ot morfo-biologicheskih osobennostej samok baltijskoj treski [Changes in the biochemical composition of eggs depending on the morpho-biological characteristics of female Baltic cod]. VNIRO Proceedings, 85, 63-67 (in Russian).

Grigorakis, K., \& Alexis, M. N. (2005). Effects of fasting on the meat quality and fat deposition of commercial-size farmed gilthead sea bream (Sparus aurata L.) fed different dietary regimes. Aquaculture Nutrition, 11(5), 341-344.

Guiet, J., Aumont, O., Poggiale, J. C., \& Maury, O. (2016). Effects of lower trophic level biomass and water temperature on fish communities: A modelling study. Progress in Oceanography, 146, 22-37.

Hadjinikolova, L., \& Zaikov, A. (2006). Investigations on the chemical composition of pike (Esox lucius L.). Bulgarian Joumal of Agricultural Science, 12(2), 337-342.

Hanna, R. G. (1984). Proximate composition of certain Red Sea fishes. Marine Fisheries Review, 46(3), 71-75.

Henderson, R. J., \& Almatar, S. M. (1989). Seasonal changes in the lipid composition of herring (Clupea harengus) in relation to gonad maturation. Journal of the Marine Biological Association of the United Kingdom, 69(2), 323-334.

Hendry, A. P., \& Berg, O. K. (1999). Secondary sexual characters, energy use, senescence, and the cost of reproduction in sockeye salmon. Canadian Journal of $\mathrm{Zo}$ ology, 77(11), 1663-1675.

Hölker, F. (2006). Effects of body size and temperature on metabolism of bream compared to sympatric roach. Animal Biology, 56(1), 23-37.

Houlihan, D. F., Costello, M. J., Secombes, C. J., Stagg, R., \& Brechin, J. (1994) Effects of sewage sludge exposure on growth, feeding and protein synthesis of dab (Limanda limanda (L.)). Marine Environmental Research, 37(4), 331-353.

Idler, D. R., \& Bitners, I. (1960). Biochemical studies on sockeye salmon during spawning migration: IX. Fat, protein and water in the major internal organs and cholesterol in the liver and gonads of the standard fish. Journal of the Fisheries Board of Canada, 17(1), 113-122.

Jabeen, F., Noureen, A., Hussain, S. M., Chaudhry, A. S., Irfan, M., Shakeel, M., Shabbir, S., Yaqub, S., Ahmad, S., \& Shaheen, T. (2015). Chemical and mineral composition of Cyprinus carpio, Labeo rohita and Wallago attu inhabiting river indus in Mianwali district. International Joumal of Biosciences, 6(5), 333-342.

Jafri, A. K. (1969). Seasonal changes in the biochemical composition of the freshwater cat-fish, Wallagonia attu (Bloch.). Hydrobiologia, 33(3), 497-506.

Jangaard, P. M., Brockerhoff, H., Burgher, R. D., \& Hoyle, R. J. (1967). Seasonal changes in general condition and lipid content of cod from inshore waters. Journal of the Fisheries Board of Canada, 24(3), 607-612.

Kangur, P. (1996). On the biology of bream, Abramis brama (L.) in Lake Peipsi in 1994. Hydrobiologia, 338(1), 173-177.

Karabanov, D. P., Pavlov, D. D., Bazarov, M. I., Borovikova, E. A., Smirnov, A. K. \& Stolbunov, I. A. (2018). Alien species of fish in the littoral of Volga and Kama reservoirs (results of complex expeditions of IBIW RAS in 2005-2017). Transactions of Papanin Institute for Biology of Inland Waters RAS, 82(85), $67-80$.

Karakoltsidis, P. A., Zotos, A., \& Constantinides, S. M. (1995). Composition of the commercially important Mediterranean finfish, crustaceans, and molluscs. Journal of Food Composition and Analysis, 8(3), 258-273. 
Karamushko, L. I. (2016). Bioenergetics of Arctic marine poikilothermic animals. Doklady Biological Sciences, 471(1), 280-283.

Khillare, C., \& Khandare, R. (2020). Food and feeding habits, length-weight relationship and condition factor of fresh water fish Mystus armatus. Asian Joumal of Fisheries and Aquatic Research, 6(3), 41-48.

Khristenko, D. S., \& Kotovska, G. O. (2017). Length-weight relationship and condition factors of freshwater bream Abramis brama (Linnaeus, 1758) from the Kremenchug Reservoir, Middle Dnieper. Turkish Joumal of Fisheries and Aquatic Sciences, 17(1), 71-77.

Kilkenny, C., Browne, W. J., Cuthill, I. C., Emerson, M., \& Altman, D. G. (2010). Improving bioscience research reporting: the ARRIVE guidelines for reporting animal research. PLOS Biology, 8(6), e1000412.

Kopylov, A. I. (2001). Ekologicheskie problemy Verhnej Volgi [Ecological problems of the Upper Volga]. YSTU, Yaroslavl (in Russian).

Krivobok, M. N., \& Tarkovskaya, O. I. (1964). Himicheskaya harakteristika zheltoperoj kambaly, treski i mintaya yugo-vostochnoj chasti Beringova morya [Chemical characteristics of yellowfin flounder, cod and pollock in the southeastern part of the Bering Sea]. VNIRO Proceedings, 49, 257-272 (in Russian).

Kruchkov, V. N., Dubovskaya, A. V., \& Fomin, I. V. (2006). Osobennosti patologicheskoj morfologii pecheni ryb v sovremennyh usloviyah [Peculiarities of pathologic morphology of fish liver in modem conditions]. Vestnik of Astrakhan State Technical University, Series Fishing Industry, 3(32), 94-100 (in Russian).

Lal, B., \& Singh, T. P. (1987). Impact of pesticides on lipid metabolism in the freshwater catfish, Clarias batrachus, during the vitellogenic phase of its annual reproductive cycle. Ecotoxicology and Environmental Safety, 13(1), 13-23.

Lall, S. P. (2003). The minerals. In: Halver, J. E., \& Hardy, R. W. (Eds.). Fish nutrition. Third Edition. Academic Press. Pp. 259-308.

Lammens, E. H. R. R., \& Hoogenboezem, W. (1991). Diets and feeding behaviour. In: Winfield, I. J., \& Nelson, J. S. (Eds.). Cyprinid fishes. Springer. Pp. 353-376.

Lapirova, T. B., Flerova, E. A., Yurchenko, V. V., \& Morozov, A. A. (2017). Protective systems of immunocompetent organs in fishes from different ecological and systematic groups. Joumal of Ichthyology, 57(3), 458 466.

Larsson, Å., Haux, C., Sjöbeck, M. L., \& Lithner, G. (1984). Physiological effects of an additional stressor on fish exposed to a simulated heavy-metal-containing effluent from a sulfide ore smeltery. Ecotoxicology and Environmental Safety, $8(2), 118-128$

Lazareva, G. A. (2016). Ocenka kachestva vod Uglichskogo vodohranilishcha po integral'nym gidrohimicheskim pokazatelyam [Estimation of water quality of Uglichsky Reservoir by integrated hydrochemical factors]. Bulletin of the Moscow Region State University, Series Natural Sciences, 2, 158-164 (in Russian).

Lazareva, V. I., Sabitova, R. Z., \& Sokolova, E. A. (2018a). Osobennosti struktury i raspredeleniya pozdneletnego (avgust) zooplanktona v vodohranilishchah Volgi [Features of the structure and distribution of the late summer (August) zooplankton in the Volga reservoirs]. Transactions of Papanin Institute for Biology of Inland Waters RAS, 82(85), 28-51 (in Russian).

Lazareva, V. I., Stepanova, I. E., Tsvetkov, A. I., Pryanichnikova, E. G., \& Perova S. N. (2018b). Kislorodnyj rezhim vodohranilishch Volgi i Kamy v period potepleniya klimata: Posledstviya dlya zooplanktona i zoobentosa [The oxygen regime in the Volga and Kama reservoirs during the period of climate warming: impact on zooplankton and zoobenthos]. Transactions of Papanin Institute for Biology of Inland Waters RAS, 81(84), 47-84 (in Russian).

Lloret, J., Shulman, G. E., \& Love, R. M. (2014). Condition and health indicators of exploited marine fishes. Wiley-Blackwell.

Lukyanenko, V. I., Natochin, Y. V., Romanenko, V. D., Shatunovskii, M. I., \& Shulman, G. E. (1983). Fiziologo-biohimicheskie osnovy iskusstvennogo razvedeniya i racional'nogo ispol'zovaniya promyslovyh ryb [Physiological and biochemical basis for artificial breeding and rational use of commercial fish]. Hydrobiological Journal, 19(3), 3-16 (in Russian).

Lund, I., Dalsgaard, J., Rasmussen, H. T., Holm, J., \& Jokumsen, A. (2011). Replacement of fish meal with a matrix of organic plant proteins in organic trout (Oncorhynchus mykiss) feed, and the effects on nutrient utilization and fish performance. Aquaculture, 321, 259-266.

Marais, J. F. K., \& Venter, D. J. L. (1991). Changes in body composition associated with growth and reproduction in Galeichthys feliceps (Teleostei: Ariidae). South African Journal of Marine Science, 10(1), 149-157.

Marshall, M. R. (2010). Ash analysis. In: Nielsen, S. S. (Ed.). Food analysis. Springer. Pp. $105-115$

Martem'yanov, V. I. (2013). Assessment of the physiological state of the common carp Cyprinus carpio L. by the water content in the organism. Inland Water Biology, 6(1), 80-84.

Martemyanov, V. I. (2013). Use of body-water content to assess the physiological state of roach Rutilus rutilus L. in natural conditions. Inland Water Biology, 6(3), 246-248

Martemyanov, V. I. (2015). Dynamics of the content of various fractions of water in the organism of roach Rutilus rutilus $\mathrm{L}$. in response to catching, transportation, and further acclimation to laboratory conditions. Inland Water Biology, 8(4), $402-405$.
Maslova, N. I. (2019). Znachenie pronicaemosti kletok pri ocenke vozrasta ryb [Permeability of cells and its importance in assessment of age of fish]. Vestnik of the Russian Agricultural Sciences, 1, 70-73 (in Russian).

Massresha, E., Mateos, H., Lewandowski, P., \& Zewdue, A. (2017). Proximate composition and fatty acid content of commercially important fish species from Ethiopian lakes: A review. World Journal of Food Science and Technology, 1(3), 105-114.

McPherson, L. R., Slotte, A., Kvamme, C., Meier, S., \& Marshall, C. T. (2011). Inconsistencies in measurement of fish condition: A comparison of four indices of fat reserves for Atlantic herring (Clupea harengus). ICES Journal of Marine Science, 68(1), 52-60

Medford, B. A., \& Mackay, W. C. (1978). Protein and lipid content of gonads, liver, and muscle of northem pike (Esox lucius) in relation to gonad growth. Joumal of the Fisheries Research Board of Canada, 35(2), 213-219.

Meyer, D. K., Westfall, B. A., \& Platner, W. S. (1956). Water and electrolyte balance of goldfish under conditions of anoxia, cold and inanition. American Journal of Physiology-Legacy Content, 184(3), 553-556.

Min, D. B., \& Ellefson, W. C. (2010). Fat analysis. In: Nielsen, S. S. (Ed.). Food analysis. Springer. Pp. 117-132.

Mineeva, N. M. (2019). Content of photosynthetic pigments in the Upper Volga reservoirs (2005-2016). Inland Water Biology, 12(2), 161-169.

Mineeva, N. M., \& Makarova, O. S. (2018). Chlorophyll content as an indicator of the modern (2015-2016) trophic state of Volga River reservoirs. Inland Water Biology, 11(3), 367-370

Mitra, T., Ganguly, S., Banerjee, S., Mahanty, A., Raman, R. K., Bhowmick, S., \& Mohanty, B. P. (2017). Nutritional composition of different size groups of catfish Rita rita (Hamilton, 1822) from river Ganga. Indian Journal of Fisheries, 64, 68-74.

Murzina, S. A., Pekkoeva, S. N., Kondakova, E. A., Nefedova, Z. A., Filippova, K. A., Nemova, N. N., Orlov, A. M., Berge, J., \& Falk-Petersen, S. (2020). Tiny but fatty: Lipids and fatty acids in the daubed shanny (Leptoclinus maculatus), a small fish in svalbard waters. Biomolecules, 10(3), 368 .

Naeem, M., \& Ishtiaq, A. (2011). Proximate composition of Mystus bleekeri in relation to body size and condition factor from Nala Daik, Sialkot, Pakistan. African Joumal of Biotechnology, 10(52), 10765-10773.

Nargis, A. (2006). Seasonal variation in the chemical composition of body flesh of Koi fish Anabas testudineus (Bloch) (Anabantidae: Perciformes). Bangladesh Joumal of Scientific and Industrial Research, 41(3), 219-226.

Njinkoue, J. M., Gouado, I., Tchoumbougnang, F., Ngueguim, J. Y., Ndinteh, D. T., Fomogne-Fodjo, C. Y., \& Schweigert, F. J. (2016). Proximate composition, mineral content and fatty acid profile of two marine fishes from Cameroonian coast: Pseudotolithus typus (Bleeker, 1863) and Pseudotolithus elongatus (Bowdich, 1825). NFS Joumal, 4, 27-31.

Nogueira, N., Fernandes, I., Fernandes, T., \& Cordeiro, N. (2017). A comparative analysis of lipid content and fatty acid composition in muscle, liver and gonads of Seriola fasciata Bloch 1793 based on gender and maturation stage. Joumal of Food Composition and Analysis, 59, 68-73.

Parrish, C. C. (1999). Determination of total lipid, lipid classes, and fatty acids in aquatic samples. In: Arts, M. T., \& Wainman, B. C. (Eds.). Lipids in freshwater ecosystems. Springer. Pp. 4-20

Payuta, A. A., \& Flerova, E. A. (2019). Some indicators of metabolism in the muscles, liver, and gonads of pike-perch Sander lucioperca and sichel Pelecus cultratus from the Gorky Reservoir. Joumal of Ichthyology, 59(2), 255-262.

Payuta, A. A., Bogdanova, A. A., Flerova, E. A., \& Miroshnichenko, D. A. (2018) Hozyajstvenno-biologicheskie priznaki i himicheskij sostav skeletnyh myshc shchuk, vyrashchennyh v hozyajstvah raznyh rybovodnyh zon [Economic and biological features and chemical composition of skeletal muscles of pike grown in farms of different fish-breeding zones]. Vestnik of Astrakhan State Technical University, Series Fishing Industry, 4, 132-138 (in Russian).

Payuta, A. A., Bogdanova, A. A., Flerova, E. A., Miroshnichenko, D. A., Malin, M. I., \& Andreeva, M. I. (2019a). Himicheskij sostav myshc ryb malyh rek Yaroslavskoj oblasti [Chemical composition of fish muscle of small rivers of the Yaroslavl Region]. Vestnik of Astrakhan State Technical University, Series Fishing Industry, 1, 112-121 (in Russian)

Payuta, A. A., Pryanichnikova, E. G., Shcherbina, G. K., Perova, S. N., \& Flerova, E. A. (2019b). Physiological parameters of bream (Abramis brama L.) in parts of the Rybinsk Reservoir of different types. Inland Water Biology, 12(2), 217-224.

Perova, S. N. (2010). Structure of macrozoobenthos in the Gorky Reservoir at the beginning of XXI century. Inland Water Biology, 3(2), 142-148.

Perova, S. N., Pryanichnikova, E. G., Zhgareva, N. N., \& Zubishina, A. A. (2018) Taksonomicheskij sostav i obilie makrozoobentosa volzhskih vodohranilishch TTaxonomic composition and abundance of macrozoobentos in the Volga cascade of reservoirs]. Transactions of Papanin Institute for Biology of Inland Waters RAS, 82(85), 52-66 (in Russian).

Persson, A., \& Brönmark, C. (2002). Foraging capacities and effects of competitive release on ontogenetic diet shift in bream, Abramis brama. Oikos, 97(2), 271-281. 
Pradhan, S. C., Patra, A. K., \& Pal, A. (2015). Seasonal analysis of the biochemical composition of muscle and liver of Catla catla in a tropical climate of India. Comparative Clinical Pathology, 24(3), 593-603.

Reinitz, G. L., Orme, L. E., \& Hitzel, F. N. (1979). Variations of body composition and growth among strains of rainbow trout. Transactions of the American Fisheries Society, 108(2), 204-207.

Ribeiro, C. A., Vollaire, Y., Sanchez-Chardi, A., \& Roche, H. (2005). Bioaccumulation and the effects of organochlorine pesticides, $\mathrm{PAH}$ and heavy metals in the eel (Anguilla anguilla) at the Camargue Nature Reserve, France. Aquatic Toxicology, 74(1), 53-69.

Rijnsdorp, A. D., \& lbelings, B. (1989). Sexual dimorphism in the energetics of reproduction and growth of North Sea plaice, Pleuronectes platessa L. Journal of Fish Biology, 35(3), 401-415.

Rudenko, O. P., Paranjak, R. P., Kovalchuk, N. A., Kit, L. P., Hradovych, N. I., Gutyj, B. V., Kalyn, B. M., Sukhorska, O. P., Butsiak, A. A., Kropyvka, S. I., Petruniv, V. V., \& Kovalska, L. M. (2019). Influence of seasonal factors on carp fish immune reactivity. Ukrainian Journal of Ecology, 9(3), 168-173.

Salam, A., \& Davies, P. M. C. (1994). Body composition of northem pike (Esox lucius L.) in relation to body size and condition factor. Fisheries Research, 19, 193-204.

Schultz, E. T., \& Conover, D. O. (1999). The allometry of energy reserve depletion: Test of a mechanism for size-dependent winter mortality. Oecologia, 119(4), $474-483$.

Shearer, K. D. (1994). Factors affecting the proximate composition of cultured fishes with emphasis on salmonids. Aquaculture, 119(1), 63-88.

Shershneva, V. I., \& Gorodovskaya, S. B. (2010). Raspredelenie energeticheskih veshchestv v tele lososej v period anadromnyh migracij [Distribution of energetic substances in salmon bodies during anadromous migrations]. The Researches of the Aquatic Biological Resources of Kamchatka and of the North-West Part of the Pacific Ocean, 17, 66-72 (in Russian).

Shoji, J., Masuda, R., Yamashita, Y., \& Tanaka, M. (2005). Effect of low dissolved oxygen concentrations on behavior and predation rates on red sea bream Pagrus major larvae by the jellyfish Aurelia aurita and by juvenile Spanish mackerel Scomberomorus niphonius. Marine Biology, 147(4), 863-868.

Shulman, G. E., \& Love, R. M. (1999). The biochemical ecology of marine fishes, Volume 36. Academic Press.

Shuter, B. J., Ihssen, P. E., Wales, D. L., \& Snucins, E. J. (1989). The effects of temperature, $\mathrm{pH}$ and water hardness on winter starvation of young of the year smallmouth bass, Micropterus dolomieui Lacepede. Journal of Fish Biology, 35(6), 765-780.

Smirnov, L. P., \& Bogdan, V. V. (1997). Vliyanie termoshoka na lipidnyj sostav plerocerkoidov nekotoryh cestod [An effect of a heat shock on lipids of plerocercoids of some cestodes]. Parasitology, 31(6), 543-551 (in Russian).

Subbotkin, M. F., \& Subbotkina, T. A. (2016).Variability of the lysozyme content in bream from the Rybinsk Reservoir in different seasons of the annual cycle. Biology Bulletin, 43(3), 257-262

Sun, S. X., Hua, X. M., Deng, Y. Y., Zhang, Y. N., Li, J. M., Wu, Z., Limbu, S. M., Lu, D. S., Yin, H. W., Wang, G. Q., Waagbø, R., Livar, F., Zhang, M. L., \& Du, Z. Y. (2018). Tracking pollutants in dietary fish oil: From ocean to table. Environmental Pollution, 240, 733-744.

Sutton, S. G., Bult, T. P., \& Haedrich, R. L. (2000). Relationships among fat weight, body weight, water weight, and condition factors in wild Atlantic salmon parr Transactions of the American Fisheries Society, 129(2), 527-538.

Takegaki, T., \& Takeshita, F. (2020). Winter mortality of young mudskipper fish: Effects of size, temperature and energy depletion. Journal of Experimental Marine Biology and Ecology, 530-531, 151436.

Tenji, D., Micic, B., Sipos, S., Miljanovic, B., Teodorovic, I., \& Kaisarevic, S. (2020). Fish biomarkers from a different perspective: evidence of adaptive strategy of Abramis brama (L.) to chemical stress. Environmental Sciences Europe, 32(1), $1-15$.

Teubner, D., Paulus, M., Veith, M., \& Klein, R. (2015). Biometric parameters of the bream (Abramis brama) as indicators for long-term changes in fish health and environmental quality - data from the German ESB. Environmental Science and Pollution Research, 22(3), 1620-1627.
Tidwell, J. H., Coyle, S. D., Bright, L. A., Van Arnum, A., \& Yasharian, D. (2003) Effect of water temperature on growth, survival, and biochemical composition of largemouth bass Micropterus salmoides. Journal of the World Aquaculture Society, 34(2), 175-183.

Tiemey, D., Donnelly, R. E., \& Caffrey, J. M. (1999). Growth of bream, Abramis brama (L.), in Irish canals and implications for management. Fisheries Management and Ecology, 6(6), 487-498.

Tocher, D. R. (2003). Metabolism and functions of lipids and fatty acids in teleost fish. Reviews in Fisheries Science, 11(2), 107-184.

Tolkachev, G. Y. (2019). Ocenka vliyaniya porovyh rastvorov donnyh otlozhenij i podzemnyh vod na kachestvo vody Ivan'kovskogo vodohranilishcha [Evaluation of the effect of detached water of bottom sediments and underground water on the quality of water of Ivankovo Reservoir]. International Research Joumal, 5(83), 48-52 (in Russian).

Tolkachev, G. Y., Kolomiytsev, N. V., \& Korzhenevskiy, B. I. (2017). Soderzhanie i formy sushchestvovaniya tyazhelyh metallov v donnyh otlozheniyah Ivan'kovs'kogo i Uglichskogo vodohranilishch [The content and forms of existence of heavy metals in the sediments of the Ivankovo and Uglich Reservoirs]. Melioration and Water Management, 4, 37-43 (in Russian).

Tran-Duy, A., Schrama, J. W., van Dam, A. A., \& Verreth, J. A. (2008). Effects of oxygen concentration and body weight on maximum feed intake, growth and hematological parameters of Nile tilapia, Oreochromis niloticus. Aquaculture, $275(1-4), 152-162$

Tsegay, T., Natarajan, P., \& Zelealem, T. (2016). Analysis of diet and biochemical composition of Nile tilapia ( $O$. niloticus) from Tekeze Reservoir and Lake Hashenge, Ethiopia. Joumal of Fisheries and Livestock Production, 4(2), 1000172.

Vdovin, A., \& Antonenko, D. (2014). Correlation between fat content and features of generative growth of arabesque greenling Pleurogrammis azonus. Journal of Coastal Life Medicine, 2(9), 679-683.

Veltishcheva, I. F., \& Tokareva, G. N. (1978). Issledovaniya obmena veshchestv baltijskoj treski v period polovogo sozrevaniya i neresta [Metabolic studies of Baltic cod during puberty and spawning]. VNIRO Proceedings, 85, 51-63 (in Russian).

Verbitsky, V. B., Lazareva, V. I., Medyantseva, E. N., Malysheva, O. A., Zhdanova, S. M., Verbitskaya, T. I., \& Grishanin, A. K. (2018). The preferred and avoidance temperatures of Thermocyclops crassus (Fischer, 1853) and their relation to the temperature of optimal, pessimal and normal performance of the species. Joumal of Thermal Biology, 78, 106-113.

Winfree, R. A., \& Stickney, R. R. (1981). Effects of dietary protein and energy on growth, feed conversion efficiency and body composition of Tilapia aurea. The Journal of Nutrition, 111(6), 1001-1012.

Yeganeh, S., Shabanpour, B., Hosseini, H., Imanpour, M. R., \& Shabani, A. (2012) Comparison of farmed and wild common carp (Cyprinus carpio): Seasonal variations in chemical composition and fatty acid profile. Czech Journal of Food Sciences, 30(6), 503-511

Yousaf, M., Salam, A., \& Naeem, M. (2011). Body composition of freshwater Wallago attu in relation to body size, condition factor and sex from Southern Punjab, Pakistan. African Journal of Biotechnology, 10(20), 4265-4268.

Yurchenko, V. V., \& Morozov, A. A. (2019). Intra-annual variability of hepatic ethoxyresorufin-O-deethylase activity in freshwater bream Abramis brama. Biological Rhythm Research, 50(5), 679-688.

Zaboukas, N., Miliou, H., Megalofonou, P., \& Moraitou-Apostolopoulou, M. (2006). Biochemical composition of the Atlantic bonito Sarda sarda from the Aegean Sea (Eastern Mediterranean Sea) in different stages of sexual maturity. Journal of Fish Biology, 69(2), 347-362

Zhiteneva, T. S. (1998). Osobennosti ekologii leshcha Abramis brama L. na etapah perekhodnyh periodah razvitiya v svyazi s problemoj ego rosta v Ivan'kovskom vodohranilishche [Features of the ecology of the bream Abramis brama L. at the stages and transitional periods of development in connection with the problem of its growth in the Ivankovo Reservoir]. Inland Water Biology, 1, 55-61 (in Russian).

Zhiteneva, T. S., Ivanova, M. N., \& Polovkova, S. N. (1984). Osobennosti pitaniya ryb v vodoemah s zaregulirovannym stokom [Features of fish nutrition in reservoirs with regulated flow]. In: Butorin, N. V., \& Poddubnyi, A. G. (Eds.). Biological resources of reservoirs. Nauka, Moscow. Pp. 132-160 (in Russian). 